\title{
Modelling the primary productivity of intertidal microphytobenthos: time scales of variability and effects of migratory rhythms
}

\author{
João Serôdio*, Fernando Catarino \\ Instituto de Oceanografia and Departamento de Biologia Vegetal, Faculdade de Ciências da Universidade de Lisboa, \\ Campo Grande, 1749-016 Lisboa, Portugal
}

\begin{abstract}
A simulation model based on the short-term variability of in situ irradiance and productive biomass, defined as the fraction of total biomass contributing to measurable production, was developed to describe the primary productivity of intertidal microphytobenthos in the Tagus estuary, Portugal. Hourly primary production was modelled based on the assumption that short-term variations in the community-level photosynthetic light response were caused by changes in productive biomass associated with the vertical migratory rhythms of motile microalgae. The hourly variability in productive biomass was quantified by non-destructively measuring the dark-level chlorophyll a fluorescence, $F_{0}$. emitted from undisturbed microphytobenthos samples. $F_{0}$ was found to be a good predictor of community-level photosynthesis versus irradiance curve parameters $\alpha$ (initial slope) and $P_{\mathrm{m}}$ (maximum photosynthesis) under the range of conditions found in situ, which allowed for the estimation of hourly production rates from hourly time series of in situ observations of $F_{0}$ and irradiance. By modelling the hourly and fortnightly variability in $F_{0}$ the model was used to calculate hourly production throughout the annual cycle, which resulted in an annual pattern characterised by fortnightly oscillations in daily production comparable in amplitude with those occurring at the seasonal time scale. A comparison of the variability in production on hourly (intraday), fortnightly (within spring-neap tidal cycles) and seasonal (month-to-month) time scales confirmed that microphytobenthic production is dominated by variability on sub-seasonal (hourly and fortnightly) time scales. Significant variability in hourly primary production rates was detected on hourly and fortnightly time scales but not among seasons. A sensitivity analysis made on the model showed that the occurrence of migratory rhythms may be expected to increase the variability in primary production both on hourly and on fortnightly time scales, and also to contribute to the high levels of primary productivity of intertidal microphytobenthos. The mean annual areal primary production was found to reach $156 \mathrm{~g} \mathrm{C} \mathrm{m}^{-2} \mathrm{yr}^{-1}$ By considering the variation of production with tidal height, the model was used to calculate the annual production of the entire intertidal area of the Tagus estuary, which resulted in a total of $4265 \mathrm{t} \mathrm{C} \mathrm{yr}^{-1}$
\end{abstract}

KEY WORDS: Microphytobenthos Primary production Modelling - Migratory rhythms Chlorophyll a fluorescence

\section{INTRODUCTION}

The estimation of annual budgets for primary production is a common objective of many of the studies conducted on microphytobenthic communities in estuarine ecosystems. Often, such budgets have been calculated by extrapolating hourly production rates to

\footnotetext{
•E-mail: joao.serodio@fc.ul.pt
}

monthly and annual periods, for which a number of different formulas have been successively developed (Leach 1970, Joint 1978, Zedler 1980, Shaffer \& Onuf 1985). More recently, the easy access to computers has allowed for the development of simulation models that are used to calculate annual production from time series of observations of relevant variables considered in the model as forcing functions (Cammen 1991, Pinckney \& Zingmark 1993a, Blanchard \& Montagna 1995, Brotas \& Catarino 1995). Simulation models are 
expected to yield more precise estimates as the assumptions made on the temporal behaviour of the forcing functions are replaced by actual data. In the modelling of the production of the microphytobenthos from estuarine intertidal flats, light and biomass have been entered as the only forcing functions. Time series of irradiance and biomass are used as inputs in biomass-specific photosynthesis versus irradiance ( $P^{\mathrm{B}}$ vs $E$ ) curves which are used as transfer functions to yield areal production estimates (Pinckney \& Zingmark 1993a, Brotas \& Catarino 1995).

However, as with most of the studies on the temporal variability of microphytobenthic production, in which annual production budgets are often based on measurements taken on a monthly basis (e.g. Leach 1970 , Cadée \& Hegeman 1974, Joint 1978, Zedler 1980 , Sundbäck 1986, Schreiber \& Pennock 1995), time series of microphytobenthic biomass or $P^{B}$ vs $E$ curve parameters entered in the simulation models are often composed of data collected monthly over the seasonal cycle (Cammen 1991, Pinckney \& Zingmark 1993a, Brotas \& Catarino 1995). This focusing of the sampling effort solely on the detection of seasonal (month-tomonth) trends, neglecting the characterisation of the variability on shorter (within-month) time scales, may cause the model to fail to realistically predict the behaviour of the variable of interest (production). Having no information on the variability on shorter time scales, variations between successive monthly observations cannot be interpreted as representing a seasonal trend because such observations are confounded or pseudoreplicated (Hulbert 1984, Underwood 1994). In the presence of within-month fluctuations, such a low sampling frequency can lead to an apparent month-to-month trend that may bear little relation to the true pattern of variation as a result of aliasing (Platt $\&$ Denman 1975). Moreover, fluctuations in production that occur on time scales too short to be resolved by the sampling frequency will not be present in the model output because the value of the forcing function has to be treated as constant throughout each whole month run by the model.

Whilst this approach implicitly assumes that most varlability in microphytobenthic production occurs on the seasonal time scale, the existing evidence indicates that this may not be the case as, particularly in the case of intertidal habitats, significant variability has been detected on fortnightly (Shaffer \& Onuf 1985 ) and humily (Pinchiney o Zingmath 1991) time scules. Fort nightly variability in microphytobenthic primary production is expected from the variation of the total daily irradiance available for photosynthesis caused by the superimposition of the tidal and day/night cycles with different period /Colijn 1982, Serodio \& Catarino 1999j, and may be predicted from models simulating the extinction of light in the water column during immersion periods (Cammen 1991, Brotas \& Catarino 1995). However, while the irradiance data entered in the models usually have an appropriately high temporal resolution (hourly), time series of irradiance available at the sediment surface have been generated using attenuation coefficients measured only monthly (Pinckney \& Zingmark 1993a) or by simply assuming that no significant irradiance levels reach the sediment surface during immersion (Cammen 1991, Brotas \& Catarino 1995).

On an hourly time scale, large variability in microphytobenthic production may be expected not only due to changes in the irradiance reaching the sediment (increased by the strong light attenuation during daytime immersions), but also because of changes in the concentration of microalgae in the photic zone of the sediment caused by the migratory rhythms. Particularly in muddy sediments, the microphytobenthos is dominated by motile diatoms capable of migrating to and from the sediment surface in synchronisation with tidal and day/night cycles (Round \& Palmer 1966, Paterson 1986, Serôdio et al. 1997). These migratory movements can cause the chlorophyll a (chl a) content of the photic zone of the sediment to vary by almost an order of magnitude in a few hours (Serôdio et al. 1997), therefore leading to large variations in the community photosynthetic rate through changes in the fraction of the light incident on the sediment surface which is absorbed for photosynthesis. The lack of a practical method for the quantification of the productive biomass (Grant 1986, Pinckney \& Zingmark 1993b)-photosynthetic biomass present in the photic zone of the sediment and actually contributing to measured photosynthesis - has limited the possibility of studying the significance of this source of variability and to incorporate hourly resolved time series of biomass in simulation models. Microphytobenthos biomass is usually quantified in depth intervals of 2 (Pinckney \& Zingmark 1991), 5 (Blanchard \& Montagna 1992) or $10 \mathrm{~mm}$ (Brotas \& Catarino 1995), making it therefore impossible to detect changes in the chl a concentration in the photic zone, usually less than $0.5 \mathrm{~mm}$ deep in muddy sediments (Serôdio et al. 1997).

Besides irradiance and productive biomass, time series of $P^{B}$ vs $E$ curve parameters must be entered in the model in order to allow for the calculation of production rates. Although physiologically induced variability in $\alpha^{\mathrm{B}}$ (initial slope of the $D^{\mathrm{B}}$ ve $E$ curve) or $P_{m}^{\mathrm{B}}$ (maximum biomass-specific photosynthetic rate) have been documented for intertidal microphytobenthos, both on hourly and seasonal time scales (Blanchard \& Cariou-Le Gall 1994), the general approach has been to construct $P$ vs $E$ curves only a few times over the year and to use the parameter estimates to run the 
model throughout the whole annual cycle (Pinckney \& Zingmark 1993a, Brotas \& Catarino 1995).

The present study addresses the modelling of intertidal microphytobenthic primary production on an hourly time scale. Unlike previous models, the variables used as forcing functions in the model, in situ irradiance, productive biomass and $P$ vs $E$ curve parameters $\alpha$ and $P_{m}$, were measured with hourly resolution. The hourly variations in productive biomass caused by the migratory movement of microalgae were quantifyied by measuring the intensity of darklevel chl a fluorescence, $F_{0}$, emitted from undisturbed microphytobenthos samples (Seródio et al. 1997). $F_{0}$ is expected to follow variations in the amount of biomass present in the photic zone of the sediment and was found to be a good predictor of community level $\alpha$ and $P_{\mathrm{m}}$. This allowed for the formulation of a model for hourly production based only on irradiance and $F_{0}$, which was used for comparing the variability in production on hourly (intraday), fortnightly (within springneap tidal cycles) and seasonal (month-to-month) time scales. By modelling the hourly and fortnightly variability of $F_{0}$, the model was extended to longer time scales (days to years), allowing for the prediction of hourly production rates for the whole year and for the estimation of annual primary production of the Tagus estuary, Portugal.

\section{METHODS}

Study site. Sampling was carried out in an extensive intertidal mudflat located near Pancas salt marsh, on the south margin of the Tagus estuary, Portugal. The Tagus estuary is a mesotidal estuary with semi-diurnal tides and tidal amplitude ranging from 1 to $4 \mathrm{~m}$ throughout the spring-neap tidal cycle. Intertidal areas are composed mainly by mudflats and its total area ranges from 20 to $40 \%$ of a total area of ca $320 \mathrm{~km}^{2}$. The sampling site is composed of fine muddy sediment, with $90.6 \%$ of particle sizes below $20 \mu \mathrm{m}$, which is representative of the intertidal areas of the estuary (Brotas \& Plante-Cuny 1998). Diatoms dominate the microphytobenthic communities of muddy sites throughout the estuary (Brotas 1995), the genera Navicula and Gyrosigma being the most abundant at the sampling site (Serôdio et al. 1997). At the sampling site, nutrient concentrations in the interstitial water average $10.0 \mu \mathrm{M} \mathrm{NO}_{3}{ }^{-}, 0.8 \mu \mathrm{M} \mathrm{NO}_{2}{ }^{-}, 4.4 \mu \mathrm{M} \mathrm{NH}{ }^{+}$, 11.0 $\mu \mathrm{M} \mathrm{PO}_{4}{ }^{3-}$, and $67.7 \mu \mathrm{M} \mathrm{Si}(\mathrm{OH})_{4}($ Cabrita \& Brotas unpubl. results). Salinity of interstitial water is highly variable, particularly during exposure periods, ranging from near 0 to more than 50 (Cabrita et al. 1999).

Sampling design. Dark-level chl a fluorescence, $F_{0}$ and $P$ vs $E$ curve parameters were measured on hourly, fortnightly and seasonal time scales, the main time scales of variability of estuarine intertidal microphytobenthic production, covering the whole range of diurnal low tide situations along the spring-neap tidal cycle. Sampling at these different time scales was conducted using a hierarchical temporal design, according to a mixed-effects nested ANOVA model in which the main nesting factor (season) is fixed, and the nested factors, day (days within the spring-neap tidal cycle) and hour (within days), representing sub-seasonal time scales, are random. Three spring-neap tidal cycles were monitored, in summer (June-July 1995), winter (November 1995), and spring (March-April 1996), periods of the year chosen so as to encompass the whole range of seasonal variation. During each of these periods, 4 days were selected for sampling. On each day, $F_{0}$ was measured every 1 to $2 \mathrm{~h}$ during daytime low and high tide periods. Two samples were followed during each day. $P$ vs $E$ curves were constructed on undisturbed samples 3 to 5 times $d^{-1}$. On different samples, primary production and $F_{0}$ were measured every 2 to $3 \mathrm{~h}$ to obtain an independent data set to validate the model.

Sampling. Sediment samples were collected during low tide using plexiglass corers $(1.9 \mathrm{~cm}$ internal diameter) and taken to the laboratory (in Lisbon, ca $20 \mathrm{~km}$ from the sampling sites), where they were placed outside in an artificial tidal system which simulated the immersion during high tide using estuarine water collected on the day of sediment sampling (Serôdio et al. 1997). Samples were immersed and exposed at times calculated from tide tables for the Tagus estuary, considering a tidal height of $2.7 \mathrm{~m}$ (relative to the Portuguese hydrographic zero). During simulated high tide, samples were covered by $\mathrm{ca} 5 \mathrm{~cm}$ of circulating water and, when occurring during daytime, samples were also darkened (to $1-5 \%$ incident sunlight intensity) using a black plastic cover. Samples remained in the tidal system overnight and all measurements were carried out in the laboratory on the day after sample collection. Samples were carefully moved to avoid disturbances in the vertical structure of the sediment.

During the 3 spring-neap tidal cycles, photosynthetically active radiation (PAR, 400 to $700 \mathrm{~nm}$ ) was measured continuously at the sediment surface at the sampling site, using an underwater quantum sensor (LI-192SA, LI-COR, Lincoln, Nebraska, USA) connected to a data logger (Delta-T Logger, Delta-T Devices, Cambridge, UK), positioned ca $1.0 \mathrm{~cm}$ above the sediment surface. Incident PAR was measured every $10 s$ and a mean value was calculated and stored every $10 \mathrm{~min}$. The sensor was visited every $3 \mathrm{~d}$ for verification of their correct position and for cleaning of any sediment deposited on the PAR sensor. Further details are given in Seródio \& Catarino (1999). These 


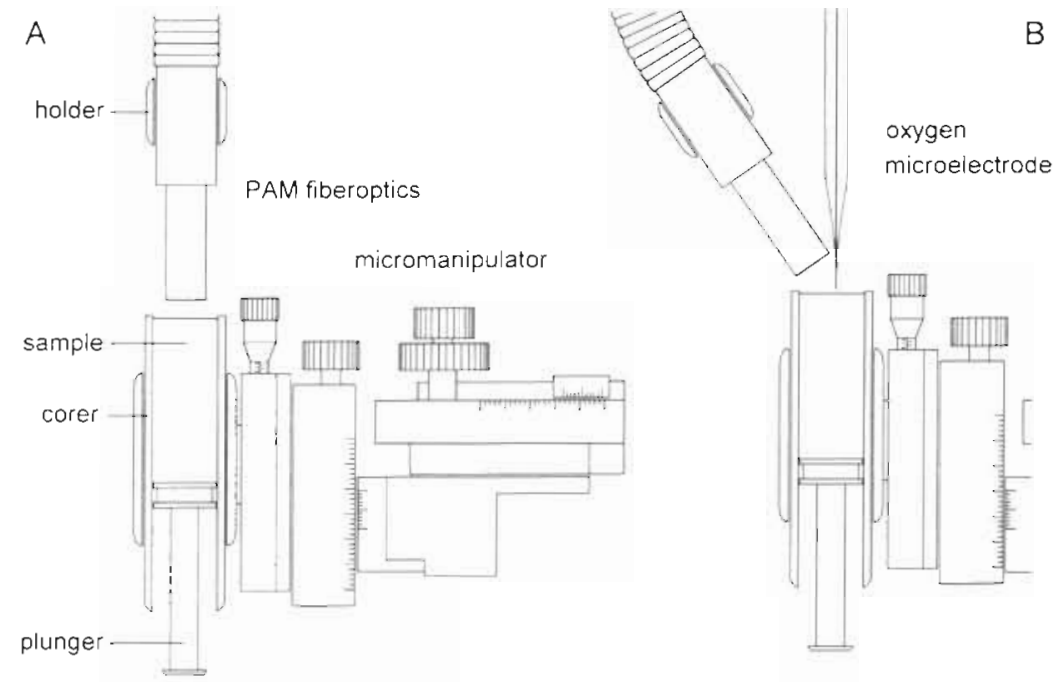

Fig. 1. The set-up used for (A) measunng chl a fluorescence, using a PAM fluorometer, and for (B) measuring photosynthesis, using oxygen microelectrodes, on undisturbed microphytobenthic samples. When measuring photosynthetic rates, the PAM fiberoptics is used to illumanate the sample surface

B type oxygen microelectrodes $(5$ to $20 \mu \mathrm{m}$ tip 737-GC model, Diamond General) according to Revsbech \& Jørgensen (1983). Oxygen microelectrodes provide rapid and nondestructive measurements that enable the measurement of photosynthetic rates with $\mathrm{chl} \mathrm{a}$ fluorescence almost simultaneously on the same undisturbed microphytobenthos sample and allow repeated measurements along the migratory cycles to be made. The microelectrode was positioned vertically within the sediment using the micromanipulator and was connected to a picoammeter (model 8100 Electrometer, Keithley Instruments, Cleveland, Ohio, USA). The measured electric current was converted into oxygen concentration using the readings in the anoxic part of the sediment as zero and the oxygen concentration in estuarine water, determined by Winkler titration. Photo-

values were later integrated hourly for the computation of hourly primary production rates. Due to instrument fallure during the March 1996 sampling period, PAR values were calculated from global radiation data measured in Lisbon (Instituto Geofísico do Infante D. Luis, Universidade de Lisboa). Hourly PAR values for the March 1996 period were calculated from a linear regression equation established between hourly PAR and hourly global radiation data measured during the July and November 1995 periods.

Measurement of chl a fluorescence and primary production. $F_{0}$ was measured using a pulse amplitude modulation (PAM) fluorometer (PAM 101 chlorophyl Fluorometer, Heinz Walz, Effeltrich, Germany) and recorded on a strip chart recorder $F_{0}$ emission was induced by a weak modulated red light (ca $0.1 \mu \mathrm{mol}$ $\mathrm{m}^{2} \mathrm{~s}^{-1}, 650 \mathrm{~nm}$ ), emitted at a frequency of $1.6 \mathrm{kHz}$ and measured applying the highest possible intensity of exciting beam, not inducing any significant variable fluorescence, and maximum instrument damping to maximise the signal to noise ratio. $F_{0}$ was measured as described by Serodio et al. (1997). The PAM fiberoptıcs (12 $\mathrm{mm}$ diameter) was positioned perpendicularly to the sediment surface, at a fixed distance of $1 \mathrm{~mm}$, and readings were recorded after signal stabilisation following daikening of the sample. The relative postions of the sample surface and the fiberoptics were set with the help of a micromanipulator (MM33, Diamond General, Ann Arbor. Michigan, USA) to which the corer was attached (Fig. 1A).

Primary production was determined by measuring gross oxygen photosynthetic production, using Clark synthesis was measured at depth intervals of $50 \mu \mathrm{m}$ until no response to darkening could be detected. Photosynthetic rates at each depth were then integrated over all depth intervals to yield the community photosynthetic rate. Illumination was provided by an FL-102 fiber illuminator (Schott KL1500 halogen lamp, Schott, Mainz, Germany), connected to the same fiberoptics used for measuring $F_{0}$, by laterally moving the corer until it is positioned below the oxygen microelectrode, and by tilting the PAM fiberoptics to allow illumination of the surface of the sample (Fig. 1B). Irradiance incident at the surface of the sediment was measured by positioning a PAR quantum sensor (LI-192SB, Li-Cor) at the leve] of the sediment surface.

$P$ vs Ecurves were constructed by exposing the same sediment core to 8 different incident irradiance levels (ca 100, 250,400,600, 800, 1000, 1300 and $1700 \mu \mathrm{mol}$ $\left.\mathrm{m}^{-2} \mathrm{~s}^{-1}\right)$ and measuring the community photosynthetic rate under each irradiance level. A different sample was used at each time of the day to avoid any artifactual effects on the migratory rhythm caused by the removal from near in situ conditions during previous measurements. To maximise the temporal resolution necessary for characterisation of the short-term variability associated with the migratory rhythms, only 2 replicated $P$ vs $E$ curves, each typically taking about 30 min to complete, were constructed at each point in the migratory cycle. $F_{n}$ was measured immediately before and after the construction of each $P$ vs $E$ curve and the parameters estimated for each curve were compared with the adjoining $F_{0}$ measurement. 


\section{MODELLING}

\section{Model formulation}

Hourly production

The modelling of hourly primary production was based on the main assumption that hourly variations in the community-level photosynthetic light response of microphytobenthos are essentially caused by variations in the amount of photosynthetic biomass in the photic zone of the sediment caused by the vertical migratory movements of microalgae. Based on this assumption, $F_{0}$ was used to predict short-term variations in the community photosynthetic light response, by quantitatively relating $F_{0}$ to $P$ vs $E$ curve parameters. One of the advantages of this approach is that, due to the extreme simplicity of $F_{0}$ measurement, parameters like $\alpha$ and $P_{\mathrm{m}}$ can be estimated with a temporal resolution impossible to obtain in any other way. The relationship between productive biomass and the community-level photosynthetic response was modelled by assuming that changes in the chl a content in the photic zone of the sediment due to migratory rhythms (followed by $F_{0}$ ) cause proportional variations in the $P$ vs $E$ curve parameters $\alpha$ and $P_{\mathrm{m}}$. A simple linear equation was therefore used to predict $\alpha$ and $P_{\mathrm{m}}$ from $F_{\mathrm{o}}$. For the comparison of the production variability under different time scales, hourly production rates were calculated from the time series of $F_{0}$ observations measured during the 3 spring-neap tidal cycles.

\section{Production during high tide}

Based on the in situ measurements of the irradiance level reaching the sediment surface during whole spring-neap tidal cycles (Serôdio \& Catarino 1999), the model was run considering that during high tide the irradiance at the sediment surface was null. This was actually observed during most days, the only exceptions being some of the days during neap tides, when a reduced fraction of the available light could be detected at the sediment surface. Because community production depends not only on the light incident on the sediment surface but also on the photosynthetic biomass present in the photic zone of the sediment, which is greatly reduced by the downward migration of microalgae during high tide, production during high tide was assumed to be negligible. Nevertheless, the maximum underestimation of the calculated daily and annual primary production rates was estimated by comparing the total production of entire spring-neap tidal cycles calculated by the model and by considering the occurrence of production during high tide. Production during high tide was calculated by running the model for the July and November fortnight periods using the irradiance data measured in situ and the maximum $F_{0}$ values observed during high tide during each of the periods.

\section{Modelling of $F_{0}$}

Since the relationship between $F_{0}$ and the $P$ vs $E$ curve parameters allows for the direct estimation of hourly production rates from $F_{0}$ and $E$ observations, the estimation of annual production budgets was approached through the modelling of the $F_{0}$ variability throughout an entire annual period. The model used for describing the hourly variation of $F_{0}$ is a modification of the model formulated by Pinckney \& Zingmark (1991). At each time step $t$ during a period of low tide, $F_{0}$ is calculated on the basis of tide angles (TIDE) and sun angles $(S U N)$ using the following equation (see Tables $1 \& 2$ ):

$$
\begin{aligned}
& F_{o}(t)=a \cos [b T I D E(t)+c]+a \sin [d S U N(t)+e] \\
& +a \cos [b T I D E(t)+c] \sin [d \operatorname{SUN}(t)+e]+f
\end{aligned}
$$

where the parameters $a$ and $f$ characterise the amplitude of the $F_{0}$ oscillation during each migratory cycle and the minimum $F_{0}$ level that is observed during high tide or night; the remaining parameters quantify the amplitude $(b$ and $d$ ) and the phase ( $c$ and $e$ ) of the oscillatory response to the tidal and the day/night cycle. A preliminary analysis of the data suggested that the large day-to-day variability in the amplitude of $F_{\circ}$ hourly fluctuation could also be attributed to variations in the absolute amount of microphytobenthic biomass potentially reaching the photic zone during the course of the daylight exposure, and not only to the migratory response to the tidal and day/night cycles. This led to the fitting of Eq. (1) to $F_{0}$ values normalised to the $F_{0}$ level measured before sunrise [pre-migration $F_{0}$ level, $\left.F_{\mathrm{o}}\left(t_{\mathrm{pm}}\right)\right]$, a time when the amount of chl a near the surface (detected by measuring $F_{0}$ ) is not yet influenced by the migratory movements. Because a preliminary analysis on $F_{0}\left(t_{\mathrm{pm}}\right)$ revealed no significant variability either on the seasonal or fortnightly time scales, the annual variation of the pre-migration $F_{0}$ level was modelled stochastically, by considering each daily $F_{0}\left(t_{\mathrm{pm}}\right)$ value as an outcome of a random variable with the probability distribution estimated from the frequency distribution of the $F_{\mathrm{o}}\left(t_{\mathrm{pm}}\right)$ observations.

For each time step $t$ during low tide, tide and sun angles were calculated by:

$$
\operatorname{TIDE}(t)=\left[\frac{t-t_{\mathrm{e}}(h)}{t_{\mathrm{i}}(h)-t_{\mathrm{e}}(h)}\right] 2 \pi
$$

and

$$
\operatorname{SUN}(t)=\left(\frac{t-t_{\mathrm{sr}}}{t_{\mathrm{ss}}-t_{\mathrm{sr}}}\right) \pi
$$


Table 1. Notation used in the text

\begin{tabular}{|c|c|}
\hline Parameter & Explanation \\
\hline$a, b, c, d, e, f$ & $\begin{array}{l}\text { Parameters of the equation used to describe the daily hourly variation of } F_{0} \text { (Eq. } 1 \text { in the text). } \\
\text { (Units: } \mathrm{V}, \mathrm{h}^{-1} \text {, dimensionless, } \mathrm{h}^{-1} \text {, dimensionless, } \mathrm{V} \text {; respectively) }\end{array}$ \\
\hline$\alpha, \alpha^{B}$ & $\begin{array}{l}\text { Initial slope of the community } P \text { vs } E \text { curve and community biomass-specific } P^{\mathrm{B}} \text { vs } E \text { curve at } \\
\text { time } t\left(\mathrm{mmol} \mathrm{O} \mathrm{O}^{-2} \mathrm{~h}^{-1}\left[\mu \mathrm{mol} \mathrm{m} \mathrm{m}^{-2} \mathrm{~s}^{-1}\right]^{-1}, \mathrm{mmol} \mathrm{O}_{2} \mathrm{mg} \mathrm{chl} \mathrm{a}^{-1} \mathrm{~h}^{-1}\left(\mu \mathrm{mol} \mathrm{m} \mathrm{m}^{-2} \mathrm{~s}^{-1}\right]^{-1}\right) \text { respectivley }\end{array}$ \\
\hline E & Irradiance $\left(\mu \mathrm{mol} \mathrm{m}{ }^{-2} \mathrm{~s}^{-1}\right)$ \\
\hline$F_{0}$ & Dark-level chl a fluorescence (V) \\
\hline$F_{0}\left(t_{\mathrm{prn}}\right)$ & Pre-migration dark-level chl a fluorescence (V) \\
\hline$h$ & Tidal height of the intertidal site (m) \\
\hline$h_{11}, h_{\mathrm{ht}}$ & Height of the water column at low and high tide (m) \\
\hline$i_{\alpha}$ & Intercept of the linear regression equation of $\alpha$ on $F_{\mathrm{o}}\left(\mathrm{mmol} \mathrm{O} \mathrm{m}^{-2} \mathrm{~h}^{-1}\left[\mathrm{\mu mol} \mathrm{m}^{-2} \mathrm{~s}^{-1}\right]^{-1}\right)$ \\
\hline$i_{P_{m}}$ & Intercept of the linear regression equation of $P_{\mathrm{m}}$ on $F_{0}\left(\mathrm{mmol} \mathrm{O} \mathrm{m}^{-2} \mathrm{~h}^{-1}\right)$ \\
\hline$m$ & Convexity of the $P$ vs $E$ curve (dimensionless) \\
\hline$P$ & Community photosynthetic rate ( $\left.\mathrm{mmol} \mathrm{O}_{2} \mathrm{~m}^{-2} \mathrm{~h}^{-1}\right)$ \\
\hline$P^{\mathrm{B}}$ & Community biomass-specific photosynthetic rate $\left(\mathrm{mmol} \mathrm{O}_{2} \mathrm{mg} \mathrm{chl} \mathrm{a}^{-1} \mathrm{~h}^{-1}\right)$ \\
\hline$P_{\mathrm{m}}$ & Maximum community photosynthetic rate $\left(\mathrm{mmol} \mathrm{O} \mathrm{O}_{2} \mathrm{~m}^{-2} \mathrm{~h}^{-1}\right)$ \\
\hline$P_{m}^{\mathrm{B}}$ & Maximum community biomass-specific photosynthetic rate $\left(\mathrm{mmol} \mathrm{O}_{2} \mathrm{mg} \mathrm{chl} a^{-1} \mathrm{~h}^{-1}\right)$ \\
\hline$s_{0}$ & Slope of the linear regression equation of $\alpha$ on $F_{0}\left(\mathrm{mmol} \mathrm{O} \mathrm{m}^{-2} \mathrm{~h}^{-1}\left[\mu \mathrm{mol} \mathrm{m} \mathrm{m}^{-2} \mathrm{~s}^{-1}\right]^{-1} \mathrm{~V}^{-1}\right)$ \\
\hline$S_{\mathrm{P}_{\mathrm{m}}}$ & Slope of the linear regression equation of $P_{\mathrm{m}}$ on $F_{\mathrm{o}}\left(\mathrm{mmol} \mathrm{O} \mathrm{m}^{-2} \mathrm{~h}^{-1} \mathrm{~V}^{-1}\right)$ \\
\hline SUN & Sun angle (radians) \\
\hline$t$ & Time (h) \\
\hline$t_{\mathrm{e}}, t_{1}$ & Time of beginning of exposure following high tide (h) \\
\hline TIDE & Tide angle (radians) \\
\hline$t_{1}, t_{h 1}$ & Time of low tide and of high tide $(\mathrm{h})$ \\
\hline$t_{s r}, t_{s s}$ & Time of sunrise and sunset (h) \\
\hline $\bar{x}_{1} s^{2}$ & Parameter (mean and variance) of the probability distribution of $F_{u}\left(t_{\mathrm{prn}}\right)\left(\mathrm{V}, \mathrm{V}^{2}\right)$ \\
\hline
\end{tabular}

Table 2. Equations used in the modelling of hourly primary production. See Table 1 for parameter definitions

Time of beginning of exposure following high tide

$$
t_{\mathrm{e}}(h)=t_{\mathrm{hl}}+\frac{t_{\mathrm{tt}}-t_{\mathrm{ht}}}{\pi} \arccos \left(\frac{2 h-h_{\mathrm{ht}}-h_{\mathrm{tt}}}{h_{\mathrm{ht}}-h_{\mathrm{it}}}\right)
$$

Time of beginning of immersion preceeding high tide

$$
t_{1}(h)=t_{h 1}+\frac{t_{h t}-t_{11}}{\pi} \arccos \left(\frac{2 h-h_{1 t}-h_{h t}}{h_{h !}-h_{h t}}\right)
$$

Tide angle at time $t$ (Eq. 2 in the text)

$$
\operatorname{TIDE}(t)=\left[\frac{t-t_{\mathrm{e}}(h)}{t_{1}(h)-t_{\mathrm{e}}(h)}\right] 2 \pi
$$

Sun angle at time $t$ (Eq. 3 in the text)

$$
\operatorname{SUN}(t)=\left(\frac{t-t_{\mathrm{st}}}{t_{\mathrm{ss}}-t_{\mathrm{s} r}}\right) \pi
$$

Dark-level chl a fluorescence at time $t(E q .1$ in the tex.t)

$F_{0}(t)=a \cos [b T I D E(t)+c]+a \sin [d \operatorname{SUN}(t)+e]$

$+a \cos [b T I D E(t)+c \mid \sin [d S U N(t)+e]+f$

Initial slope of the community $P$ vs $E$ curve at time $t$ as a function of $F_{0}$

$$
\alpha(t)=s_{r t} F_{0}(t)+i_{i s}
$$

Maximum community photosynthetic rate at time $t$ as a function of $F_{\mathrm{o}}$

$$
P_{\mathrm{m}}(t)=S_{p_{m}} F_{0}(t)+i_{p_{m}}
$$

Community photosynthetic rate at time $t$ (Eq. 4 in the text)

$$
P(t)=\frac{\alpha(t) P_{\mathrm{m}}(t) E(t)}{\left\{\left[P_{\mathrm{m}}(t)\right]^{m}+[\alpha(t) E(t)]^{m}\right\}^{\frac{1}{m}}}
$$

where $t_{\mathrm{e}}$ is the time of the beginning of the exposure following the previous high tide, $t_{1}$ is the time of the beginning of the immersion preceding the following high tide, and $t_{\mathrm{sr}}$ and $t_{\mathrm{ss}}$ are the time of sunrise and sunset, respectively. Both $t_{e}$ and $t_{1}$ are functions of the tidal height of the intertidal site, $h$, and were calculated from times and water heights of low and high tides obtained from tide tables for the Tagus estuary, assuming a sinusoidal curve for the variation of the water height between successive low or high tides (Eqs. A \& $B$, Table 2). This model differs from the model of Pinckney \& Zingmark (1991) in 2 main aspects. First, tide angles are not calculated from the time of 2 successive high tides, but from $t_{\mathrm{e}}$ and $t_{1}$, enabling the model to be run for intertidal sites of different tidal height. Second, in ordor to botter describe the accentuated peaking typically observed in $F_{0}$ during low tide, a third term, $\cos [b T I D E(t)+c] \times \sin [d S U N(t)+e]$, was included to represent the effect of the synergistic interaction between the 2 factors. 


\section{Estimation of model parameters}

The relationship between $F_{0}$ and $\alpha$ and between $F_{0}$ and $P_{\mathrm{m}}$ was quantitatively defined by calculating the slope and the $y$-intercept of linear regression equations fitted to paired measurements of $F_{0}$ and $\alpha\left(s_{\alpha}\right.$ and $i_{\alpha,}$ Eq. F; Table 2$)$ and of $F_{o}$ and $P_{m}\left(s_{P_{m}}\right.$ and $i_{P_{m}}, E q . G$; Table 2). Due to the potential variability in the convexity of the depth-integrated $P$ vs $E$ curves constructed on intact microphytobenthic communities, caused by the interaction between light attenuation and the chl a vertical distribution within the photic zone of the sediment (Terashima \& Saeki 1985, Leverenz 1988, Henley 1993), community $P$ vs $E$ curves were fit to the model of Bannister (1979):

$$
P(E)=\frac{\alpha P_{\mathrm{m}} E}{\left[\left(P_{\mathrm{m}}\right)^{m}+(\alpha E)^{m}\right]^{\frac{1}{m}}}
$$

which includes the shape parameter $m(1 \leq m \leq \infty)$ to represent the convexity of the curve. This model was adjusted using a quasi-Newton iterative estimation procedure and only the curves for which the model explained more than $90 \%$ of total variance were considered for further analysis.

In the calculation of hourly production rates from $F_{0}$ observations, the slope and the $y$-intercept of the $\alpha$ vs $F_{\mathrm{o}}$ and the $P_{\mathrm{m}}$ vs $F_{\mathrm{o}}$ linear regression equations were estimated separately from the data collected during each spring-neap tidal cycle. In the modelling of the annual production, these parameters were estimated from the entire data set. The parameters of the model describing the $F_{0}$ hourly variation were estimated by fitting Eq. (1) to the entire set of daily time series of $F_{0}$ observations normalised to $F_{\mathrm{o}}\left(t_{\mathrm{pm}}\right)$, using the same iterative estimation procedure. The frequency distribution of the $F_{0}\left(t_{\mathrm{pm}}\right)$ observations was used for the selection (and parameter estimation) of a continuous probability distribution to model $F_{o}\left(t_{\mathrm{pm}}\right)$. The criteria used for the selection of the probability distribution was the agreement between observed and expected frequencies, tested by a Kolmogorov-Smirnov test with Lilliefors correction (Sokal \& Rohlf 1981).

\section{Model run}

For the comparison of the time scales of production variability, hourly production rates were calculated from the hourly time series of observations of $E, F_{0}$ and $t_{\hat{\alpha}}$ and $t_{1}$, and the values of $s_{\alpha}, i_{\alpha}, s_{\mathrm{P}_{m}}$ and $i_{\mathrm{P}_{\mathrm{m}}}$ estimated for each spring-neap tidal cycle. In the calculation of hourly primary production for annual periods, the model used the irradiance at the sediment surface, tidal height, slopes and $y$-intercepts of the $\alpha$ and $P_{\mathrm{m}}$ vs $F_{\mathrm{o}}$ linear regressions, and the parameters of the probability distribution describing $F_{0}\left(t_{\mathrm{pm}}\right)$, as forcing functions to calculate the value of the state variables $F_{0}, \alpha$ and $P_{\mathrm{m}}$ and hourly community primary production rate, $P$ (Fig. 2). The irradiance data from which $t_{\mathrm{s} r}$ and $t_{\mathrm{ss}}$ were calculated for each day were obtained from annual time series of hourly global radiation measured in Lisbon. $t_{\mathrm{e}}$ and $t_{\mathrm{i}}$ were calculated from tide tables for the Tagus estuary, using Eqs. (A) \& (B) (Table 2). For each day, a random value was generated from the probability distribution used to describe $F_{\mathrm{o}}\left(t_{\mathrm{pm}}\right)$ and the obtained daily production rate recorded.

The model was run for a whole year repeatedly and a mean value and a standard deviation for the production rate were calculated for each day of the year and for the entire annual period. The number of repetitions was determined by applying a stopping rule based on the desired precision of the estimate of the mean annual production rate (Serôdio 1993). Model code was written in MS Visual Basic for Applications and the values of the state variables were recorded at each time step in MS Excel spreadsheets.

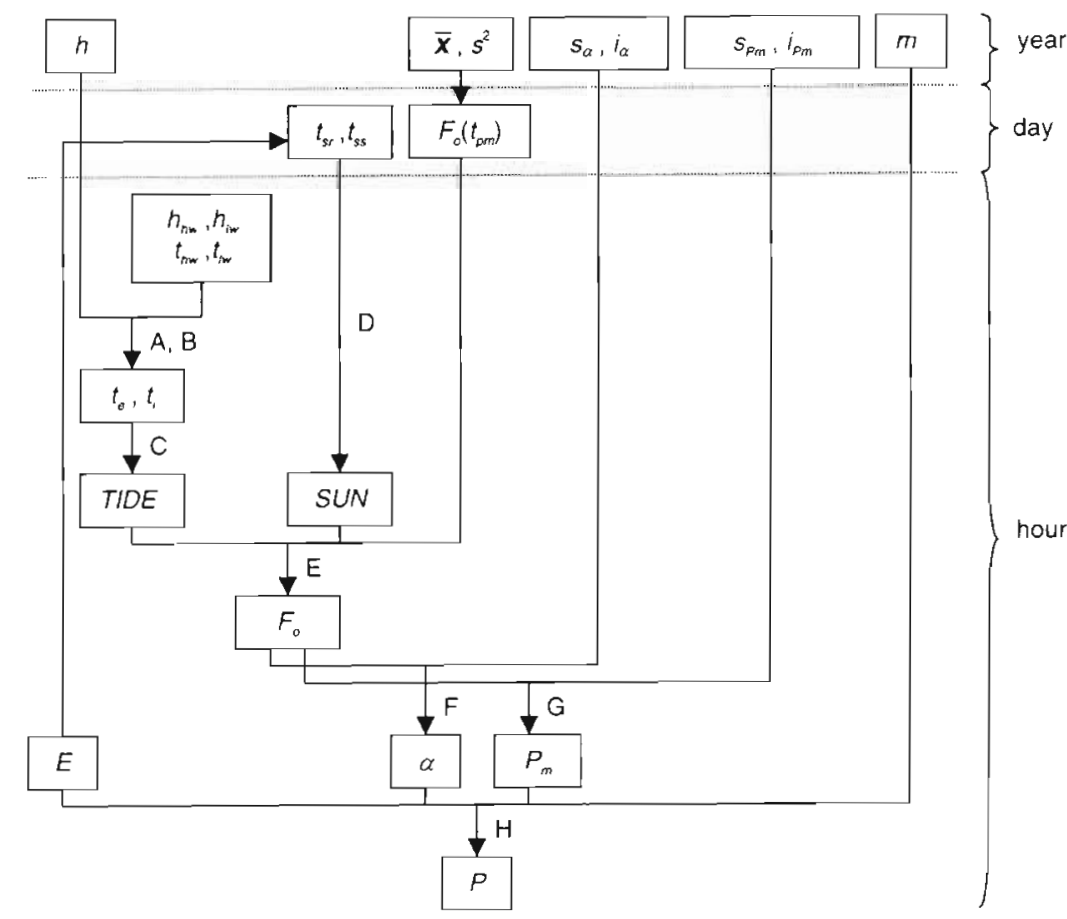

Fig. 2. Hourly primary production model, showing the time scales of variability of the forcing functions and parameters considered in the model (hourly, daily or seasonal). See list of equations for letters $\mathrm{A}$ to $\mathrm{H}$ (Table 2) 


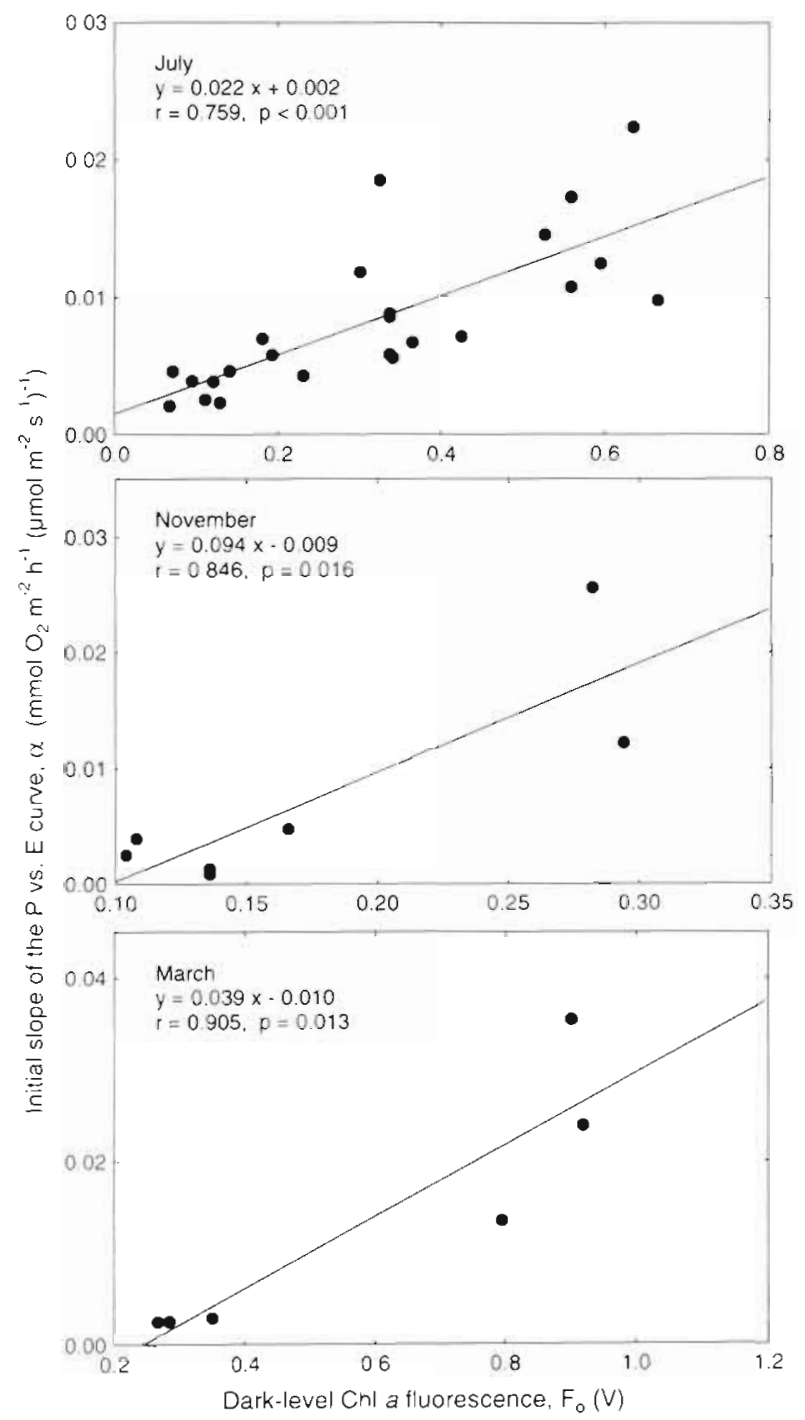

Fig. 3. Linear relationship between the initial slope of the community $P$ vs $E$ curve, $\alpha$, and dark-level chl a fluorescence, $F_{0}$ in undisturbed microphytobenthos samples during low tide periods

\section{Model validation}

The predictive ability of the model was tested on a data set different from the one used for the estimation

Table 3 Model parameters and estimated values

\begin{tabular}{|c|c|c|c|c|c|c|}
\hline & \multicolumn{4}{|c|}{$F_{0}$ vs $\alpha$ and $P_{m}$} & \multicolumn{2}{|c|}{ Model for } \\
\hline & jui & Fus & Mái & Aill & & $E_{0}(t)$ \\
\hline & $2157 \times 10^{2}$ & $9.433 \times 10^{2}$ & $3.927 \times 10^{-2}$ & $2587 \times 10^{-2}$ & $a$ & 0.826 \\
\hline$i_{e}$ & $1.517 \times 10^{-3}$ & $-9.192 \times 10^{-1}$ & $-9.546 \times 10^{3}$ & $0.349 \times 10^{3}$ & $b$ & -0.647 \\
\hline$s_{p}$ & 27.155 & 98.367 & 45.138 & 31.722 & c & 2.167 \\
\hline$i_{p}^{\prime}$ & 0.547 & -9.863 & -10.367 & -0.655 & d & -1.496 \\
\hline$m$ & 3.99 & 6.29 & 2.23 & 4.21 & e & 3916 \\
\hline & & & & & $f$ & 1.830 \\
\hline
\end{tabular}
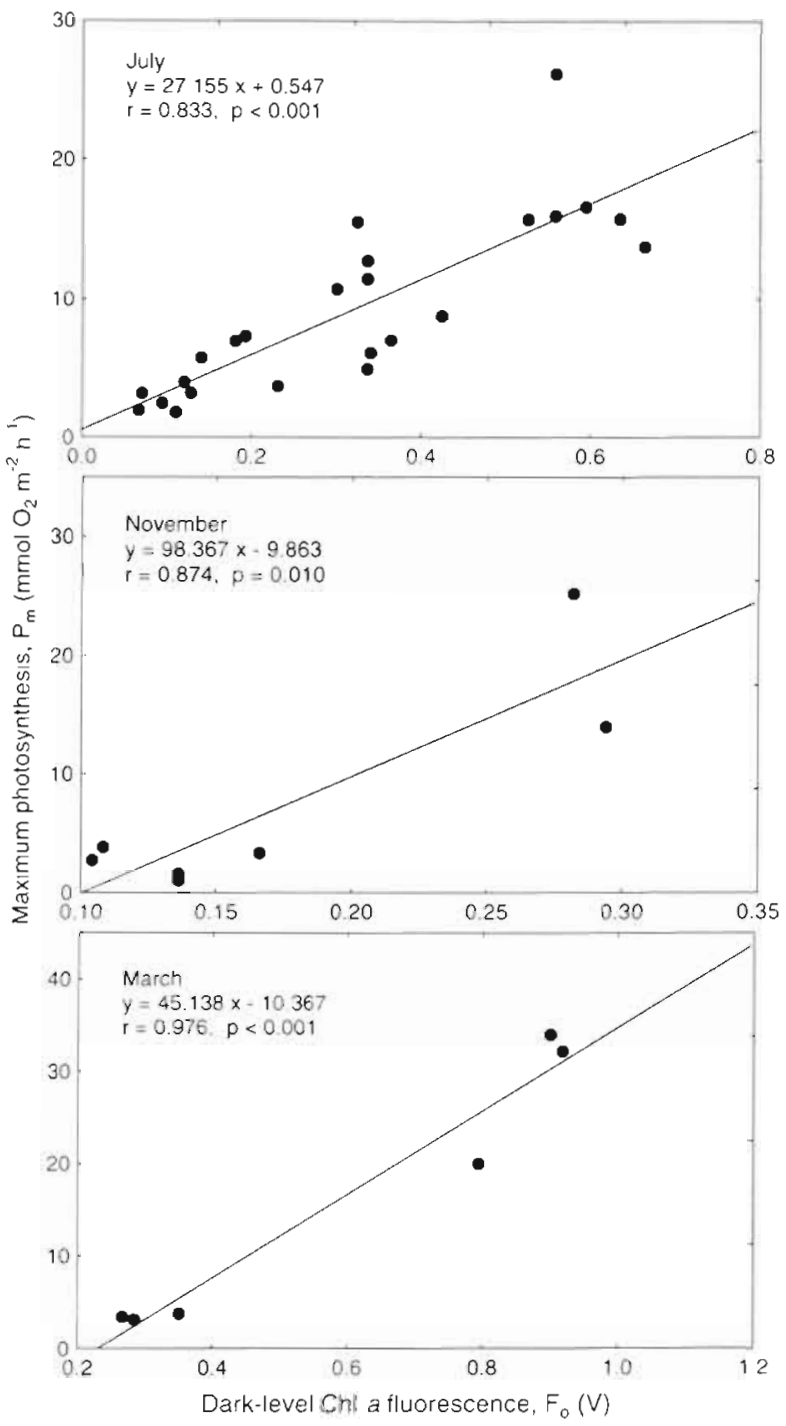

Fig. 4. Linear relationship between the community maximum photosynthesis, $P_{m}$, and dark-level chl a fluorescence, $F_{1, j}$ in undisturbed microphytobenthos samples during low tide periods

of the model parameters. Model-predicted hourly primary production rates were compared with observations made independently on a different set of samples. Type II regression analysis was used when comparing predicted and observed production rates as none of these variables could be considered as dependent on the other (Ricker 1973, Laws \& Archie 1081). Whon a significant regression was found, confidence limits for its slope and $y$-intercept were calculated to test if the slope was significantly different from 1 and if the $y$-intercept was significanlly different from 0 (Ricker 1973, Draper \& Smith 1981). 
Fig. 5. Hourly variation of dark-level chl a fluorescence, $F_{\text {or }}$ during 3 spring-neap tidal cycles observations $(O)$ and model predictions (Eq. 1, ….). Shaded bars represent periods of high tide and black bars represent night periods
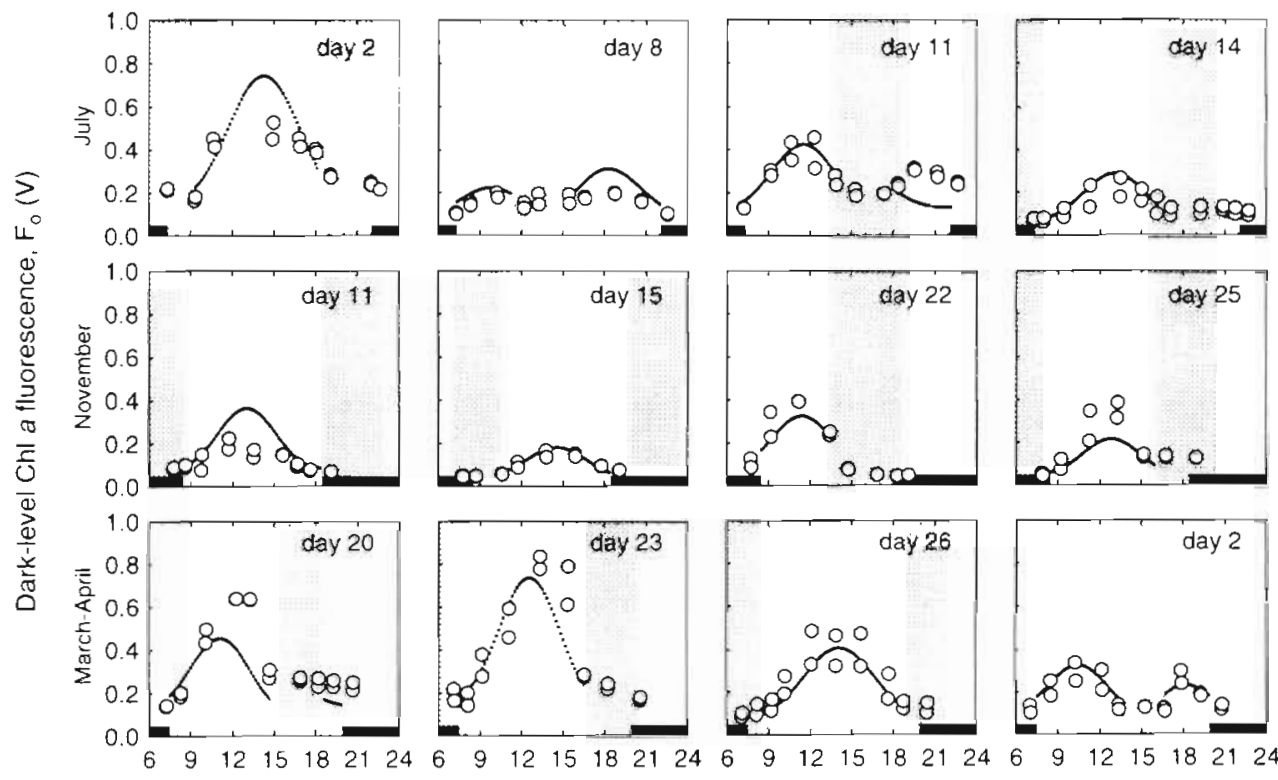

Time of day (hours)

\section{RESULTS}

\section{Estimation of model parameters}

\section{$P$ vs $E$ curve parameters and $F_{\mathrm{o}}$}

A linear relationship was found between $F_{0}$ and $P$ vs $E$ curve parameters $\alpha$ and $P_{\mathrm{m}}$ either when considering each fortnight period separately or when pooling the data from the 3 periods. Highly significant regression equations were found in all cases when $\alpha$ and $P_{\mathrm{m}}$ were regressed against $F_{\mathrm{o}}$ (Figs. $3 \& 4$ ). The values estimated for the slopes and $y$-intercepts of the regression equations relating $\alpha$ and $P_{\mathrm{m}}$ with $F_{\mathrm{o}}$ are presented in Table 3. Because no significant correlations were found between $m$ and $F_{0}$, $m$ was considerd as constant and its average value was used to run the model (Table 3).

Modelling of $F_{\circ}$

Using the parameters estimated from the entire $F_{0}$ data set, Eq. (1) could reasonably describe the $F_{0}$ hourly variation pattern and its change throughout the spring-neap tidal cycle (Fig. 5). In spite of some inability to predict day-to-day variations in the amplitude of the $F_{0}$ fluctuations, Eq. (1) predicts the main features of the $F_{o}$ hourly and fortnightly variability, as the number of peaks per day, the timing of each peak during the low tide period, and the variation of the peak amplitude along the spring-neap tidal cycle. The frequency distribution $F_{0}\left(t_{\text {pm }}\right)$ presented a marked asymmetry (Fig. 6) and was successfully described by the $\log$-normal distribution $\ln \left[F_{\mathrm{o}}\left(t_{\mathrm{pm}}\right)\right]-\mathrm{N}(-2.236$,
0.193) (Kolmogorov-Smirnov statistic $D=0.079, \mathrm{p}>$ $0.20 \mathrm{~ns})$.

\section{Model validation}

When using $F_{o}$ time series as a forcing function, the model predictions were in good agreement with the production measurements made on independent samples (Fig. 7). In all cases the slope of the fitted model II regression equation was not significantly different from 1, and its $y$-intercept was not significantly different from 0 . When modelling production for a whole annual period, by modelling $F_{\mathrm{o}}$ through Eq. (1) and estimating $s_{\alpha,}, i_{\alpha}, s_{\mathrm{P}_{\mathrm{m}}}$ and $i_{\mathrm{P}_{\mathrm{m}}}$ from the entire data set,

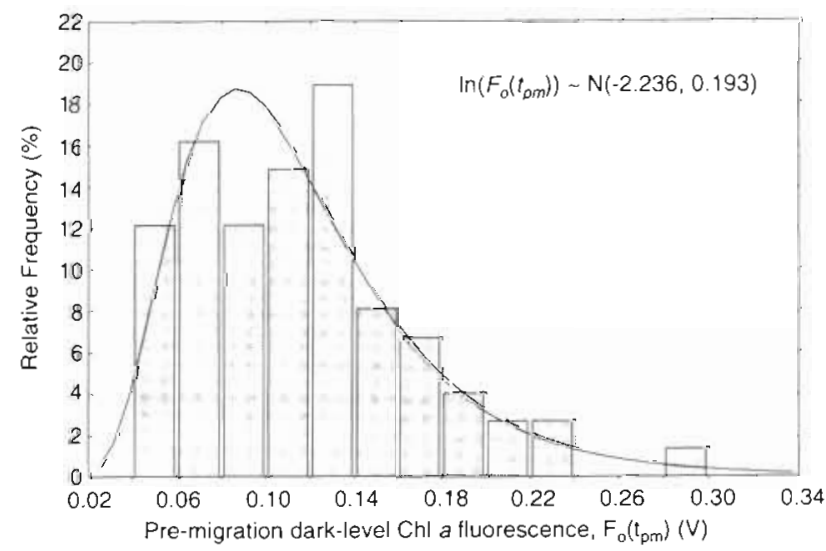

Fig. 6. Frequency distribution of observations of pre-migration dark-level chl a fluorescence, $F_{o}\left(t_{p m}\right)$, and fitted lognormal distribution 

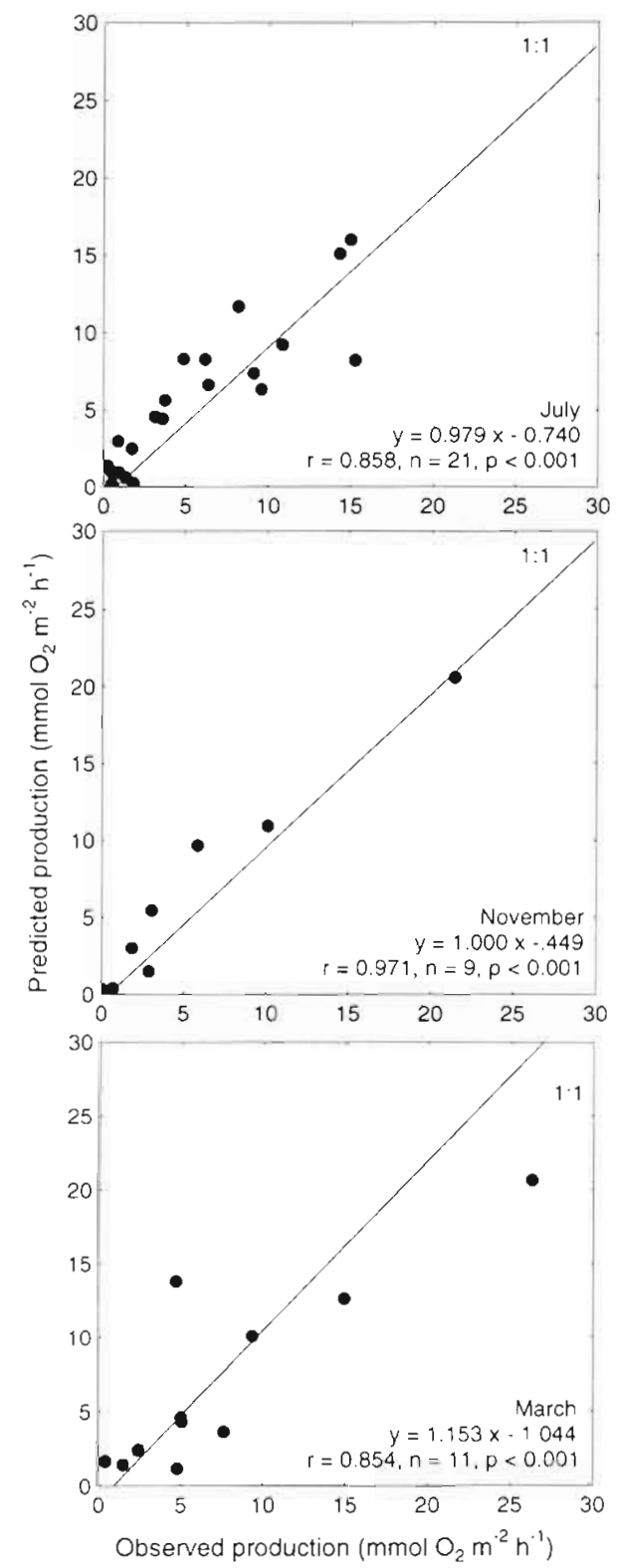

Fig. 7. Model-predicted versus observed hourly primary production rates for each of 3 spring-neap tidal cycles. Predicted production rates were calculated using time series of darklevel chl a fluorescence level, $F_{0}$ observations as forcing function. In all cases, the slope and the $y$-intercept were not significantly different from 1 and 0 , respectively

predicted and observed hourly primary production rates were significantly correlated and the $y$-intercept and the slope of the regression cquation did not differ significantly from 0 and from 1 (Fig. 8). Calculated valwes for $t_{c}$ and $t_{\text {s }}$ showed good agreement with the observations $\left(t_{2}: \mathrm{r}=0.9996, \mathrm{p}<0.001 ; t_{1}: \mathrm{r}=0.9993 ; \mathrm{p}<\right.$ 0.001). Production during high tide, calculated from the in situ irradiance measurements and the maximum $F_{0}$ values observed during high tide during each of the

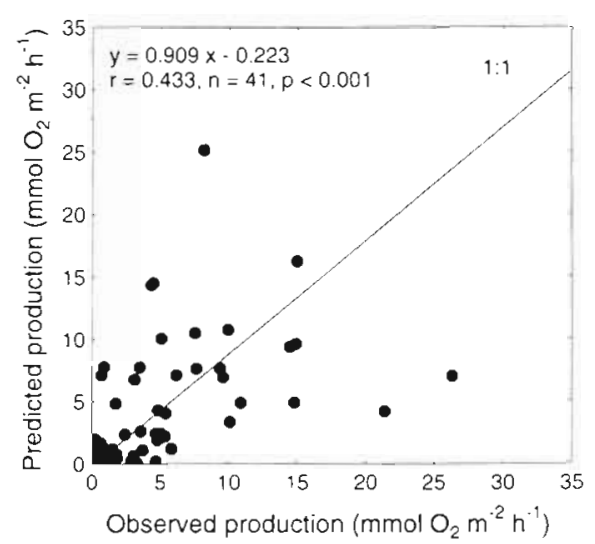

Fig. 8. Model-predicted versus observed hourly primary production rates for the entire data set. Dark-level chl a fluorescence level, $F_{0}$, was modelled by Eq. (1). The slope and the $y$-intercept were not significantly different from 1 and 0 . respectively

spring-neap tidal cycles $\left(F_{0}=0.20 \mathrm{~V}\right.$ in July and $F_{0}=$ $0.15 \mathrm{~V}$ in November), was found to represent only 6.2 and $3.2 \%$ of the total production of the July and the November fortnight periods, respectively.

\section{Time scales of variability}

Highly variable patterns were found for primary production rates both on hourly and fortnightly time scales (Fig. 9). In general, maximum hourly production rates were obtained during days when the low tide exposure occurred near the middle of the day, and minimum rates near spring tides, when the opposite situation occurred. Main exceptions were days when very low irradiance levels reached the sediment surface during low tide due to heavy cloud cover (11 and 15 November; 2 April). However, while daily patterns of hourly production varied considerably from day to day within each springneap tidal cycle, a similar range of day-to-day variation in hourly production was found in all seasons.

The significance of the relative contribution of the seasonal (month-to-month), fortnightly (within springneap tidal cycles), and hourly (intraday) time scales to the total primary production variability were compared through a 4-factor mixed-effects nested ANOVA model, in which the variability introduced by each of these time scales is represented respectively by the fixed-effect factor Season, and random-effect factors Day (nested within Season) and Hour (nested within Day). Because production was calculated from $F_{0}$ measurements taken on the same cores throughout each day ( 2 cores were monitored each day), the hourly variability in production in each core within each day was represented in the ANOVA model as a repeated measurement factor orthogonally combined with 


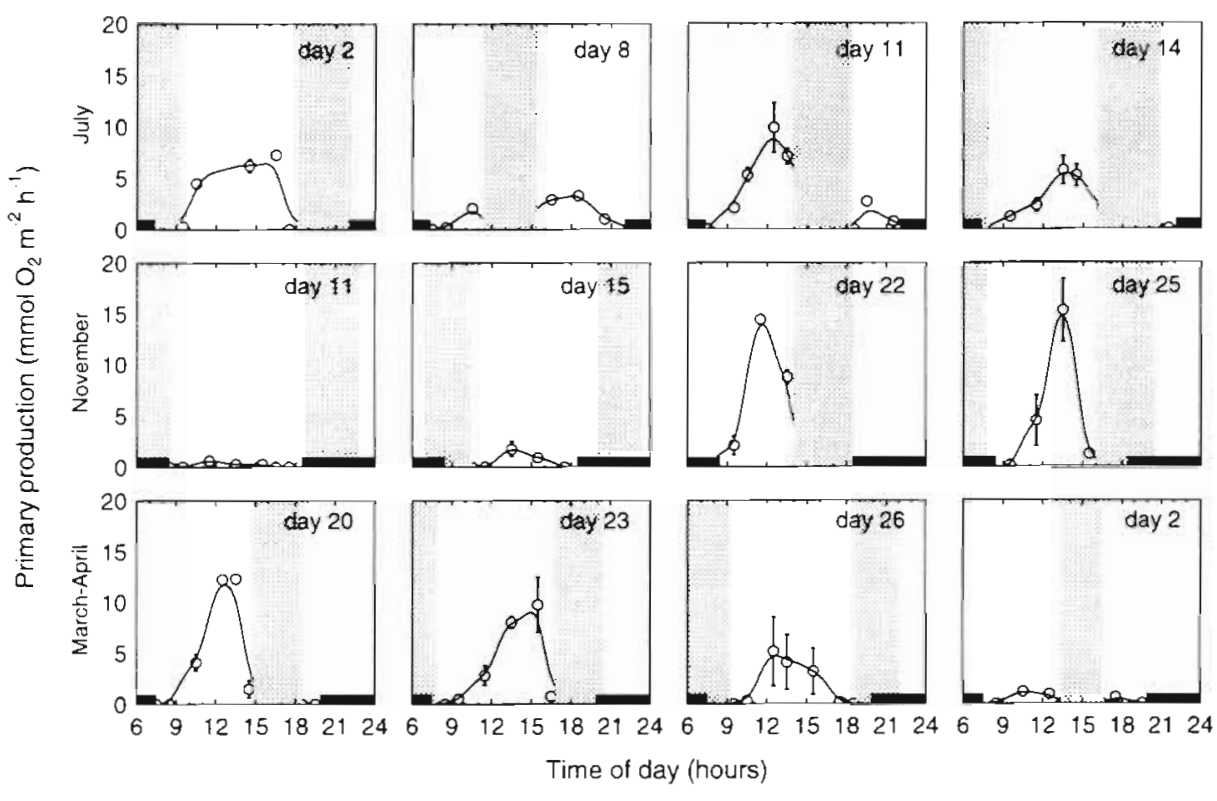

Fig. 9. Daily variation of hourly primary production rates during 3 spring-neap tidal cycles. Mean and standard deviation of hourly production rates calculated from $F_{0}$ observations on 2 samples. Shaded bars represent periods of high tide and black bars represent night periods
Core, a random factor representing the inter-core variability. The orthogonal combination between Core and Hour was nested within each level of factor Day. Through the testing of the interaction between factors Core and Hour, this ANOVA model allows the intraday pattern of production variation between different days within the same spring-neap tidal cycle or among different spring-neap tidal cycles to be compared. As suggested from Fig. 9, significant variability in hourly primary production rates was detected on hourly ( $\mathrm{p}<$ 0.001 ) and fortnightly $(\mathrm{p}<0.001)$ time scales but not among seasons ( $p=0.688$, Table 4 ). Furthermore, the highly significant Day $\times$ Hour interaction indicates that not only production varied significantly from hour to hour within each day and from day to day within each fortnight cycle, but also the intraday pattern of variation varied significantly among days within each spring-neap tidal cycle.

\section{Annual production}

Running the model for an entire year resulted in an annual pattern of daily primary production charac-

Table 4. Summary of analysis of variance: hourly primary production rates

\begin{tabular}{|lrrrr|}
\hline Source of variation & df & Mean squares & \multicolumn{1}{c|}{$F$} & \multicolumn{1}{c|}{$\mathrm{p}$} \\
\hline Season & 2 & 7.387 & 0.390 & 0.688 \\
Day (Season) & 9 & 18.924 & 14.577 & $<0.001$ \\
Hour [Day (Season)] & 11 & 76.190 & 6.283 & $<0.001$ \\
Season $\times$ Hour & 22 & 11.435 & 0.943 & 0.541 \\
Day $\times$ Hour & 99 & 12.126 & 30.360 & $<0.001$ \\
\hline
\end{tabular}

terised by a strong fortnightly quasi-cyclic variability superimposed on an underlying seasonal trend (Fig. 10). This pattern was evident not only in the mean daily production (calculated on the outcome of 38 runs of the model) but also in individual outcomes of the model. Fortnightly fluctuations followed the irradiance availability at the sediment surface throughout the spring-neap tidal cycles, which caused oscillations in daily production comparable in amplitude with those occurring at the seasonal time scale. Throughout the whole year daily production and tidal amplitude oscillate with the same period (fortnight) but with an almost opposite phase of oscillation. Maximum daily production occurs during neap tides, shortly before the minimum in tidal amplitude, and minimum production values occur during spring tides, shortly before maximum tidal amplitude (Fig. 11).

The presented results refer to only 1 year, 1990, since inter-annual variability in model output was very low. When the model was run for 4 different years (1987 to 1990), the pattern of daily production was essentially the same and the estimates of annual production varied by less than $7 \%$. For this 4 yr period, annual areal production ranged from 12.47 to $13.34 \mathrm{~mol} \mathrm{O}_{2} \mathrm{~m}^{-2} \mathrm{yr}^{-1}$ or, converting oxygen production $\left(\mathrm{mol} \mathrm{O}_{2}\right.$ ) to carbon assimilation ( $\mathrm{g}$ C) assuming a 1:12 ratio (Cammen 1991, Pinckney \& Zingmark 1993a), from 149.6 to $160.1 \mathrm{~g} \mathrm{C} \mathrm{m}^{-2} \mathrm{yr}^{-1}$. The estimation of the annual primary production of the entire intertidal area of the Tagus estuary was approached by running the model for the whole range of tidal heights (from 0.1 to $4.1 \mathrm{~m}$, at $0.1 \mathrm{~m}$ intervals) and by extrapolating the annual areal production values calculated for each tidal height for the total intertidal area corresponding to the same 


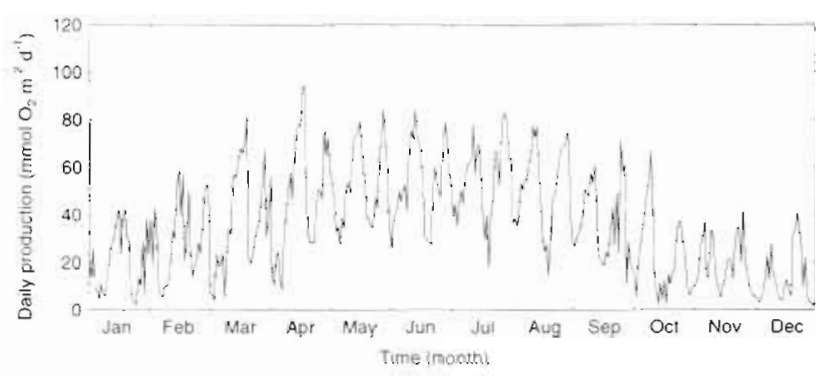

Fig. 10. Model-predicted annual varlation of mean daily primary production rate

tidal height interval. For each tidal height interval, the total intertidal area was calculated from average heights of $300 \times 300 \mathrm{~m}$ areas computed from bathymetry charts for the Tagus estuary. From the annual areal primary production rate predicted for each tidal height interval, an annual production map for the intertidal areas of the Tagus estuary was constructed (Fig. 12). For the total $114.48 \mathrm{~km}^{2}$ of intertidal area of the Tagus estuary, mean annual primary production was estimated to reach $4265.1 \mathrm{tC} \mathrm{yr}^{-1}$.

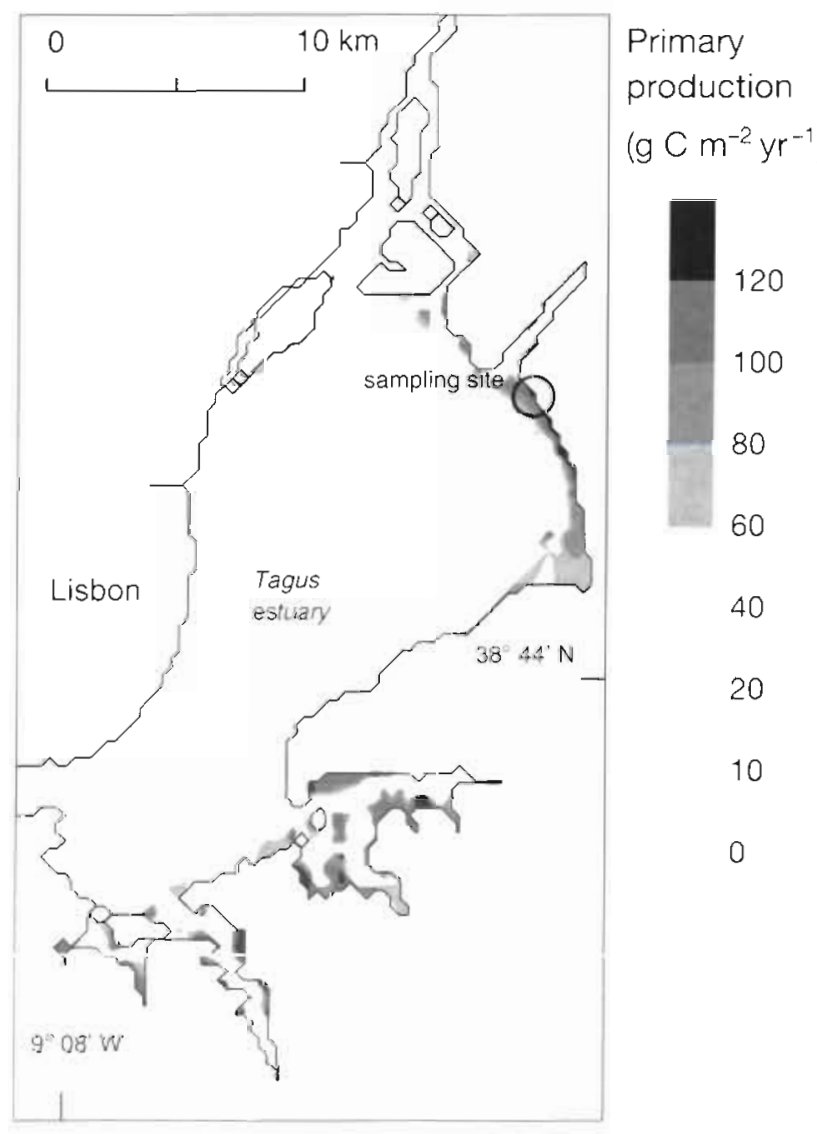

Fig. 12. Spatial distribution of model-predicted areal annual primary production rate in the Tagus estuary

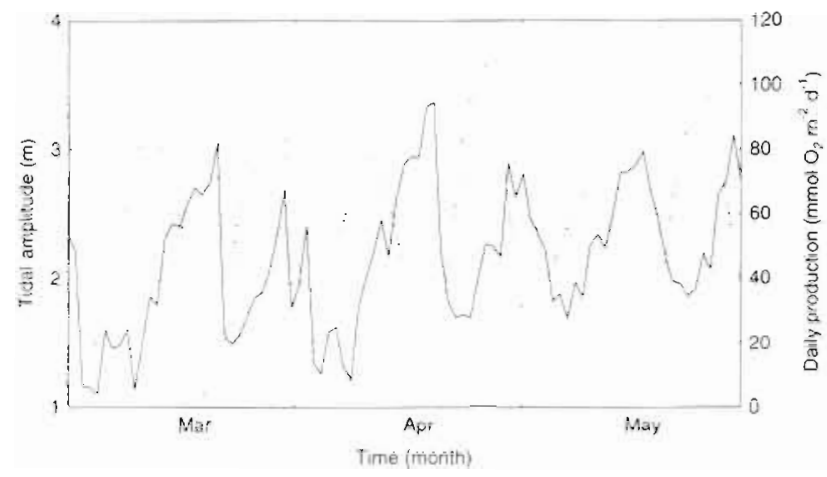

Fig. 11 Fortnightly variation of tidal amplitude (…....) and model predicted mean daily primary production rate $(-)$

\section{Effects of migratory rhythms on time scales of variability}

The effects of migratory rhythms on the temporal patterns of variability of microphytobenthic primary production were studied through sensitivity analysis of the model, by comparing model outputs obtained by running the model with and without considering the hourly variation in $F_{0}$. On an hourly time scale, the presence of migratory rhythms causes an increase in the variability of production relative to the situation in which photic biomass is considered to remain constant (Fig 13). However, because the amplitude of the hourly variation in productive biomass depends on the duration of the exposure periods and varies along the spring-neap tidal cycle, the difference between both situations was larger when low tide coincided with the middle of the day (Fig. 13). Therefore, by increasing the hourly variability in production differently on different days in the spring-neap cycle, the migratory rhythms also increase the production variability at the fortnightly time scale. This can be better seen from the spectral analysis (periodogram) of time series of mean diily production calculated for the period 1987 to 1990 , considering and without considering the presence of migratory rhythms (Fig. 14) The magnitude of the peaks in the periodogram quantifies the fraction of total variability taking place on each time scale. In both cases, 2 peaks are clearly identified. The first corresponds to cyclic variation with a period of $14.8 \mathrm{~d}$ (fortnightly variability), and the second corresponds to cyclic variation with a period of 365.0 d (seasonal variabisty). When itythms are not considered, production variability on the fortnighty time scale represents $32.6 \%$ of the variability on the seasonal time scale; when rhythms are considered, the relative importance of the fortnightly variability increases more than 2 -fold, representing $65.3 \%$ of the seasonal variability. 


\section{DISCUSSION}

\section{Model formulation}

The basis of the present model is the establishment of productive biomass, defined as the fraction of total algal biomass contributing to measurable primary production, as the main predictor of the short-term variability in the microphytobenthic community-level photosynthetic light response. This was due to the possibility to vertically resolve the biomass present in the photic zone of the sediment given by the measurement of the chl a fluorescence ( $F_{0}$ level) emitted from undisturbed samples. This allowed for the detection of short-term variations in the community productive biomass, and for the quantitative description of the effect of these variations in the community photosynthetic Iight response.

The modelling of hourly production was based on the assumption that short-term variations in production rates were essentially caused by changes in the productive biomass associated to the migratory movements of microalgae; changes in the photophysiological characteristics of the microalgal population affecting the community efficiency in photosynthetically converting the absorbed light were assumed to only marginally contribute to the observed variability in production rates. The assumption that hourly variations in $P$ vs $E$ curve parameters are mainly due to migratory rhythms was also implicit in the formulation of the production model of Pinckney \& Zingmark (1993a).

In spite of the fact that the present model does not consider various factors often necessary for the modelling of photosynthesis of microalgae, it was able to successfully predict hourly production rates under the full range of in situ conditions. The main cause for this is likely to be the large amplitude of hourly variation in productive biomass in comparison with the effects on the community photosynthetic light response caused by other factors, like temperature changes (Blanchard et al. 1997) or physiological adaptation (Blanchard \& Cariou-Le Gall 1994). Although rapid and large variations in temperature are typical of the intertidal environment (Serôdio \& Catarino 1999), the community production may be expected to be mostly temperature independent. First, because under light limitation photosynthesis is controlled by the temperature-independent parameter $\alpha$ (Henley 1993), the effect of varying temperature are expected only under saturating irradiance levels. Second, because even when the irradiance level at the sediment surface reaches saturating

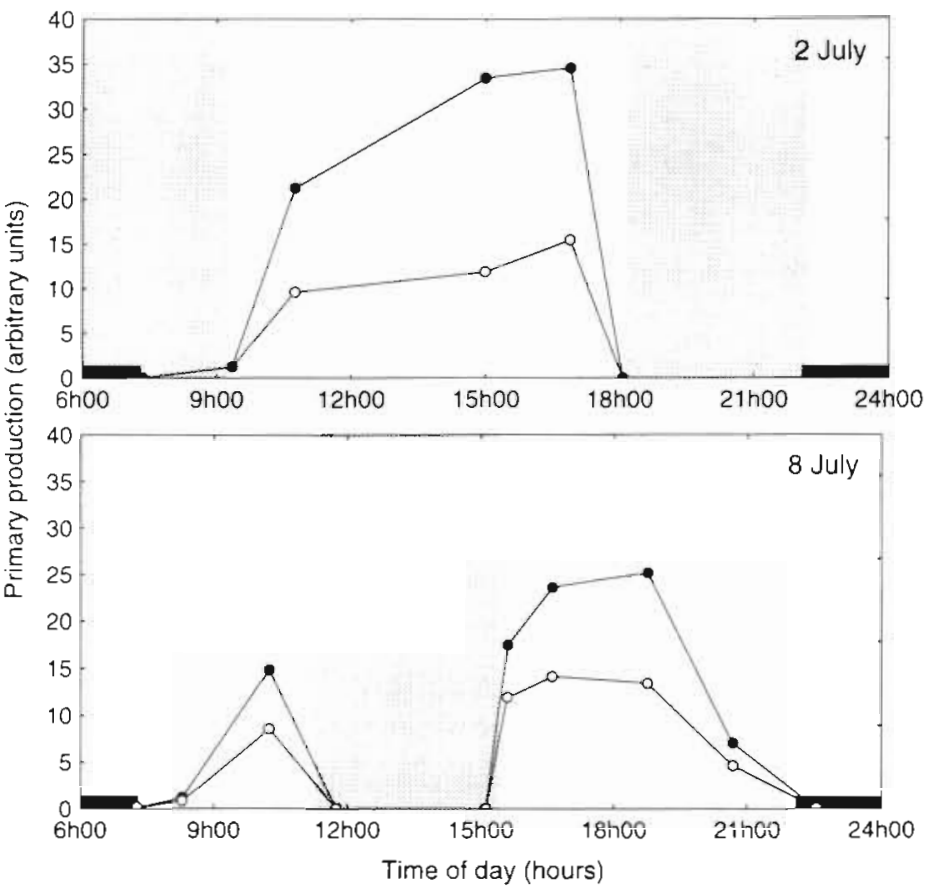

Fig. 13. Effect of migratory rhythms on hourly variability of primary production in 2 distinct tidal situations along 1 spring-neap tidal cycle. Example comparing model predictions calculated when considering the effect of migratory rhythms on $F_{\mathrm{o}}(\bullet)$ and when $F_{\mathrm{o}}$ is considered as constant (o). Hourly primary production rates calculated from $F_{o}$ values normalised to $F_{o}\left(t_{p m}\right)$. The daily production rate calculated considering the migratory rhythms was 2.4 (Day 2) and 1.7 (Day 8 ) times bigger than when $F_{0}$ is considered as constant. Shaded bars represent periods of high tide and black bars represent night periods

levels, the community photosynthetic rate may be expected to be mostly dominated by $\alpha$, since a large part of the microalgal population is exposed to much lower, limiting irradiances (Blanchard \& Montagna 1995). On the other hand, variations in $\alpha^{B}$ or $P_{m}^{B}$, attributed to adaptations to the variable intertidal environment, attained maximum values that did not exceed $100 \%$ (Blanchard \& Cariou-Le Gall 1994), while variations in productive biomass typically range from 300 to 900\% (Seródio et al. 1997; Fig. 5). Even smaller variations in photophysiological response were observed for undisturbed microphytobenthos under in situ conditions (Kromkamp et al. 1998). Other factors known to potentially affect microphytobenthic production, such as nutrient or carbon limitation, and desiccation seem not to have influenced the photosynthetic rate of undisturbed assemblages under near in situ conditions. Because desiccation depends on the duration of the exposure periods, its effects on production cannot be excluded in the case of intertidal sites higher than the site sampled in this study. With regard to nutrients, the present model shares with all the other primary production models formulated for intertidal microphy- 


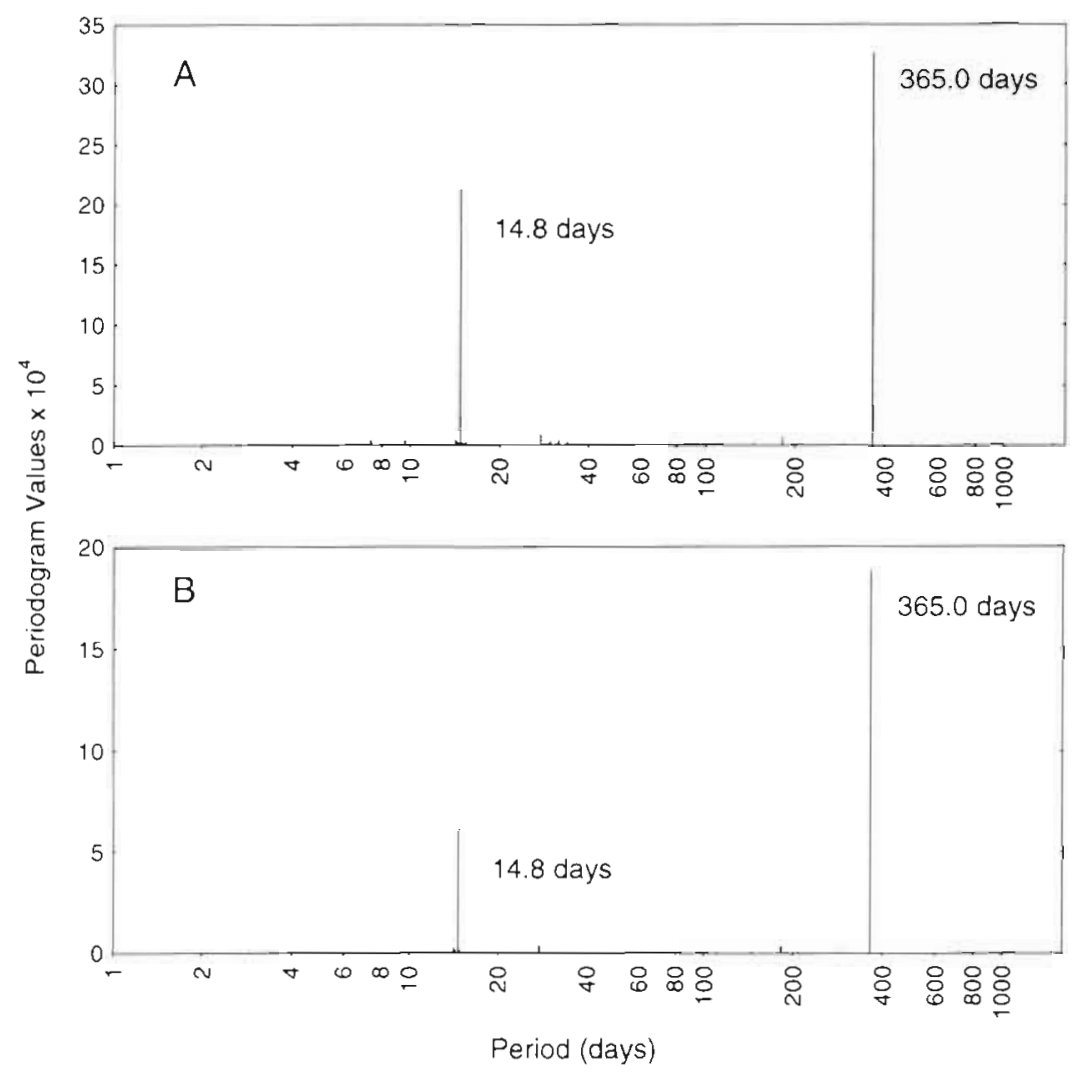

Fig. 14. Effect of migratory rhythms on the time scales of variability of primary production. Periodograms of time series of daily primary production rates obtained by running the model for a continuous 4 yr period, comparing model predictions calculated $(A)$ when considering the effect of migratory rhythms on $F_{0}$ and $(B)$ when considering $F_{0}$ as constant

tobenthos (Admiraal et al. 1988, Cammen 1991, Pinckney \& Zingmark 1993a, Blanchard \& Montagna 1995. Brotas \& Catarino 1995) the assumption that benthic primary production is not nutrient-limited, as nutrient levels in the estuarine sediments are typically well above limiting values (MacIntyre et al. 1996).

Due to its importance as the predictor of the $P$ vS $E$ curve parameters, most of the modelling effort concerned the hourly and fortnightly variability of $F_{\mathrm{o}}$. On the basis of the approach to model $F_{0}$ was the assumption that, at any point in time, the amount of biomass present in the photic zone of the sediment was dependent on the biomass present in the upper layers of the sediment that may potentially reach the photic zone, and on the duration of the diurnal period of exposure diring low tide, defining a potcntial migrotory ampli tude which is only fully expressed when diumal periods of low tide are sufficiently long. This potentially productive biomass is expected to increase due to cell accumulation following population growth or decrease due to cell resuspension or grazing, and its variability was approached by measuring $F_{0}$ before dawn
$\left[F_{\mathrm{o}}\left(t_{\mathrm{pm}}\right)\right]$, as a way to avoid the variability associated to the migratory rhythms. Due to the variation in tidal currents along the spring-neap tidal cycle, microphytobenthic biomass is expected to vary fortnightly following varying resuspension intensity (Shaffer \& Onuf 1985). However, in spite of the fortnightly variation of the tidal currents over the tidal flats of the Tagus estuary (Vale \& Sundby 1987, Cabrita et al. 1999), no significant correlation was found between $F_{0}\left(t_{\mathrm{prn}}\right)$ and the tidal amplitude in any of the studied springneap tidal cycles. Probably due to the periodic resuspension and deposition of the upper layers of the sediment during flood and ebb, $F_{\mathrm{o}}\left(t_{\mathrm{pm}}\right)$ measurements taken on successive sampling days were uncorrelated, which lead to the stochastic approach used in the modelling of its variability.

\section{Time scales of variability}

The interference between the tidal and the day/ night cycles cause the estuarine intertidal environment to be dominated by strong variability in a number of different time scales. While the hourly, fortnightly or seasonal variability of microphythobenthic primary production has been studied separately in different studies (Shaffer \& Onuf 1985, Pinckney \& Zingmark 1991), the relative importance of the variability occurring on each of these time scales has not yet been compared. This is of interest because the significance of seasonal variations cannot be assessed without being compared to the variability taking place on shorter time scales (Cloern \& Nichols 1985). Also, because such information is needed to evaluate the validity of the assumptions usually made either on the extrapolation of hourly to annual production rates or on the use of monthly time series of observations as forcing functions in simulation models. The significance of the contribution of the variability on each time scale to total variability may be appropriately tosted by using temporally nosted sampling designs, in which a series of successively smaller temporal scales is nested within the scale above. Temporally nested designs were first proposed as a way to pre. vent pseudoreplication in time, in the context of the detection of environmental impacts (Stewart-Oaten et al. 1986, Underwood 1994). 
The use of a sampling design of this type allowed for the finding that microphytobenthic primary productivity is dominated by variability on sub-seasonal (hourly and fortnightly) time scales. These results have important consequences for the design of sampling programs for the characterization of the temporal patterns of variation of microphytobenthic productivity. The usual practice of measuring production monthly throughout the year does not provide information on the within-month variability and may yield erroneous seasonal patterns due to aliasing. By using such a low sampling frequency relative to the main time scales of variability, the apparent seasonal pattern that is obtained depends to a great extent on the regularity and on the timing of the sampling dates within the springneap cycles. Furthermore, because hourly production is closely dependent on productive biomass, the extrapolation from hourly to monthly or annual rates must take into consideration not only the variability of the irradiance reaching the sediment surface but also the amount of photosynthetic biomass actually exposed to this irradiance. In this context, time series of monthly biomass content of the upper millimetres ( 2 to $5 \mathrm{~mm}$ ) of sediment are of little value when used as forcing functions since they do not represent most of the aspects of the temporal variability of productive biomass.

The predominance of fortnightly over seasonal variability in microphytobenthic productivity predicted for the Tagus estuary is not likely to be a generalised feature of estuarine ecosystems, as it is determined by factors associated to the particular geographic location of each estuary. In general, seasonality is expected to increase with latitude, following the higher month-tomonth variations in irradiance and temperature, as shown in a recent comparison of results from different estuaries (MacIntyre et al. 1996). In the Tagus estuary, the fortnightly variability in daily production is caused by the variation in the daily available irradiance along the spring-neap tidal cycle: during spring tides, low tide occurs early in the morning and late in the afternoon; conversely, during neap tides, low tide occurs in the middle of the day. In other estuaries, different tidal regimes and less turbid water may reduce the relative importance of the spring-neap cycle on benthic production. It should be noted that, while the model output generally confirms the high fortnightly variability superimposed on the seasonal trend (Fig. 10), fluctuations larger than those predicted by the model may be expected. The model may underestimate daily production during neap tides, when some light is more likely to reach the sediment surface during inundation, and therefore underestimate the amplitude of the fortnight fluctuations.

The coincidence of maximum daily production rates with minimum resuspension of benthic biomass during neap tides (Fig. 11, considering the tidal amplitude as an indicator of the resuspension intensity) is likely to cause a marked fortnightly variability in the availability of microphytobenthic biomass for the estuarine food web. In the period between spring and neap tides, the simultaneous increase in daily production and decrease in resuspension intensity favours the accumulation of microphytobenthic biomass on the tidal flats, but at the same time a reduction in the transfer of benthic biomass for the pelagic food web. On the opposite phase of the spring-neap cycle, while biomass on the tidal flats is expected to decrease following the reduction of daily production and the increase in resuspension rates, the availability of benthic microalgae for filter feeders or benthic grazers in other areas of the estuary is expected to increase. Such a process would contribute to the attenuation of the impact of the fortnightly variation in intertidal primary production at the ecosystem-level primary and secondary productivity.

\section{Effects of migratory rhythms}

The sensitivity analysis made on the model showed that the occurrence of migratory rhythms may be expected to increase the variability in primary production both on hourly and on fortnightly time scales. However, besides affecting the production variability, migratory rhythms contribute to the increase in the primary productivity of intertidal microphytobenthos in absolute terms. The capacity to vertically migrate enables the microalgae to actively search, under the limitations imposed by space avajlability, for optimal conditions for photosynthesis along the steep gradients within the upper layers of the sediment, and thus maximise photosynthetic rates (Admiraal 1984, Lamontagne et al. 1989). By doing so, microalgae can also avoid the exposure to photosynthesis-limiting factors, such as excessive irradiance, desiccation at the sediment-air interface and local nutrient depletion. Nevertheless, of greater importance seems to be the endogenous and geotropic nature of the migratory movements. Motile diatoms were shown to be able to migrate upward to the surface after a resuspension/deposition event, in complete darkness and removed from the influence of the tides (Serôdio et al. 1997). This ability is especially relevant in the intertidal environment, where the periodic resuspension and deposition of upper layers of the sediment during flood and ebb repeatedly homogenises the upper sediment layers, burying below the photic zone cells that were previously near the surface. Through endogenously controlled upward migration, cells that would otherwise remain randomly distributed within the sediment are able to reach the photic zone and contribute to increasing the community production. 
The possibility to actively search for optimal light levels within the photic zone of the sediment may result in a lesser need to undergo photophysiological adaptations, and allowed for the modelling of the community-level photosynthesis without considering time-dependence in the biomass-specific photosynthetic light response (Macedo et al. 1998).

Temporal variability in ecosystem-level processes may be categorised into 2 types (Margalef 1992): sudden changes, driven from outside the system and usually unpredictable, that result in destruction of organised structure, and auto-organizative changes, driven from inside and predictable. In the case of intertidal benthic productivity, migratory rhythms appear as the auto-organizative process that counterbalance the external perturbation caused by tidal resuspension. The development of migratory rhythms may then be seen as an adaptation to the predictably of the disturbances caused by the tidal action. Although the tidal disturbance may be unpredictable in terms of the magnitude of the disruptive force (destruction of structure), it is highly predictable in terms of frequency (time of occurrence) (Sousa 1984). The adaptative significance of the migratory ability also complies with the hypothesis that aquatic organisms develop adaptations not only to cope with environmental variability but also to actively exploit it (Harris 1980, Legendre \& Demers 1985). Vertical migration may be of adaptative value in enhancing the survival probability ability of individual cells, either by allowing them to return to the photic zone after burrowing (upward migration in the beginning of the low tide) or by preventing resuspension by tidal currents (downward migration before inundation) (Heckman 1985). However, as in the case of the migratory behaviour of planktonic species, benthic microalgae may migrate to exploit vertically inhomogeneous resource supply conditions (Raven 1995). In the benthic environment, this would be favoured by the similarity between the vertical dimension of the gradients of relevant resources (light, carbon, nutrients) and the size of individual microalgae, making it possible for the motile cells to cover the whole range of resource availability by moving a distance equivalent to a few cell lengths. An active exploitation of environmental variability is likely to happen in relation to light, since vertical novements within the light gradient may provide a more rapid, flexible and energetically cheaper way to optimise photosynthesis in comparison to photophysiological adaptaivins ät the level of the phostosynthetic apparatus.

\section{Annual production}

Considering the interannual variation in the annual estimates, a maximum range of 149.6 to $160.1 \mathrm{~g} \mathrm{C} \mathrm{m}^{-2}$ $\mathrm{yr}^{-1}$ and a mean value of $155.8 \mathrm{~g} \mathrm{C} \mathrm{m}^{-2} \mathrm{yr}^{-1}$ are obtained for the annual areal production rate of the studied intertidal microphytobenthos of the Tagus estuary. These values are within the range of estimates reported for other estuaries (for a recent review, see MacIntyre et al. 1996), and close to previous estimates made for this estuary. Based on measurements of community net photosynthesis, Brotas \& Catarino (1995) estimated annual production as 47 and $178 \mathrm{~g} \mathrm{C} \mathrm{m}^{-2}$ $\mathrm{yr}^{-1}$, values calculated for sites at tidal heights of 1.4 and $3.1 \mathrm{~m}$, respectively. The use of different methodologies to measure microphytobenthic photosynthesis and the different methods used to extrapolate from hourly to annual production rates, makes a direct comparison between the estimates obtained in both studies difficult. However, when the present model is run for the tidal height of $3.1 \mathrm{~m}$, and the resulting estimate is converted to net production $180 \%$ of gross production, value estimated for similar microphytobenthos communities in the Tagus estuary; Brotas 1995), a mean value of $164.9 \mathrm{~g} \mathrm{C} \mathrm{m}^{-2} \mathrm{yr}^{-1}$ is obtained, $7.3 \%$ lower than the estimate of Brotas \& Catarino (1995).

Because the model was not validated for tidal heights or locations other than those used for estimating its parameters, some caution must be used in the analysis of the results obtained concerning the estimation of annual production rate for the whole estuary. The main causes for failure in the model predictions are the variation in the fraction of microalgae that are motile and overall biomass, which are usually lower in sandier sediments, and the effects of desiccation on sites that are not inundated during neap tides (tidal height above $2.9 \mathrm{~m}$ ). Also, variations over space in the community physiological light response, associated to differences in taxonomic composition or to photoacclimation to different light regimes, may contribute to errors in the model predictions.

The annual gross primary production for the whole intertidal area of the Tagus estuary estimated by taking into consideration the representativeness of the different tidal heights and the production estimated for each tidal height interval, 4265.1 t $\mathrm{C} \mathrm{yr}^{-1}$, was substantially different to the value obtained by directly extrapolating the areal production rate estimated at a single tidal height for the entire intertidal area, $17858.9 \mathrm{t} \mathrm{C}$ $\mathrm{yr}^{-1}$. This highlights the importance of the development and validation of improved production models that consider the variability of production rates with tidul hoight in the estimation of ecosyctem-lovel production.

Acknowledgements. The authors wish to thank Paulo Cartaxana and Teresa Cabrita for help with the field work, and Margarida Ramos for assistance in the use of oxygen microelectrode instrumentation. The bathymetry data for the Tagus 
estuary were kindly provided by Prof. Joảo Gomes Ferreira. We gratefully acknowledge Vanda Brotas for critical comments on the manuscript. We also thank the Instituto Geofísico do Infante D. Luis for providing global radiation data. This work was supported by Junta Nacional de Investigaçào Científica e Tecnológica, grant PFMRH $359 / 92$ and Praxis XXI BD/5045/95 to J.S. This work is a contribution to the European Union ELOISE Programme (ELOISE No. 103) and was carried out in the framework of the Marine Science and Technology programme (MAST III) under the NICE project contract MAS3-CT96-0048

\section{LITERATURE CITED}

Admiraal W (1984) The ecology of estuarine sediment-inhabiting diatoms. Prog Phycol Res 3:269-322

Admiraal W, van Arkel MA, Baretta JW, Colijn F, Ebenhöh W, de Jonge VN, Kop A, Ruardij P, Schröder HGJ (1988) The construction of the benthic submodel. In: Baretta JW, Ruardij P (eds) Tidal flat estuaries: simulation and analysis of the Ems estuary. Ecological studies, Vol 74. SpringerVerlag, Berlin, p 105-152

Bannister TT (1979) Quantitative description of steady-state, nutrient-satured algal growth, including adaptation. Limnol Oceanogr 24:76-96

Blanchard GF, Cariou-Le Gall V (1994) Photosynthetic characteristics of microphytobenthos in Marennes-Oleron bay, France. J Exp Mar Biol Ecol 182:1-14

Blanchard GF, Montagna PA (1992) Photosynthetic response of natural assemblages of marine benthic microalgae to short- and long-term variations of incident irradiance in Baffin Bay, Texas. J Phycol 28:7-14

Blanchard GF, Montagna PA (1995) Assessment of a brown tide impact on microalgal benthic communities in Baffin Bay (Texas) in 1990 using a primary production model. Oceanol Acta 18:371-377

Blanchard GF, Guarini JM, Gros P, Richard P (1997) Seasonal effect on the relationship between the photosynthetic capacity of intertidal microphytobenthos and temperature. J Phycol 33:723-728

Brotas V (1995) Distribuiçào espacial e temporal do microfitobentos no estuário do Tejo (Portugal): pigmentos fotossintéticos, povoamentos e produção primária. PhD thesis Universidade de Lisboa, Lisbon, and Université de la Mediterranée Aix-Marseille, Marseille

Brotas V, Catarino F (1995) Microphytobenthos primary production of Tagus estuary intertidal flats (Portugal). Neth J Aquat Ecol 19:333-339

Brotas V, Plante-Cuny MR (1998) Spatial and temporal patterns of microphytobethic taxa of estuarine tidal flats in the Tagus Estuary (Portugal) using pigment analysis by HPLC. Mar Ecol Prog Ser 171:43-57

Cabrita T, Vale C, Catarino $F$ (1999) The efect of tidal range on the flushing of ammonium from intertidal sediments of the Tagus estuary, Portugal. Oceanol Acta 22:291-301

Cadée GC, Hegeman J (1974) Primary production of the benthic microflora living on tidal flats in the Dutch Wadden Sea. Neth J Sea Res 8:260-291

Cammen LM (1991) Annual bacterial production in relation to benthic microalgal production and sediment oxygen uptake in an intertidal sandflat and an intertidal mudflat. Mar Ecol Prog Ser 71:13-25

Cloern JE, Nichols FH (1985) Time scales and mechanisms of estuarine variability, a synthesis from studies of San Francisco Bay. Hydrobiologia 129:229-237

Colijn F (1982) Light absorption in the waters of the Ems-Dol- lard estuary and its consequences for the growth of phytoplankton and microphytobenthos. Neth J Sea Res 15: $196-216$

Draper NR, Smith H (1981) Applied regression analysis. John Wiley, New York

Grant T (1986) Sensitivity of benthic community respiration and primary production to changes in temperature and light. Mar Biol 90:299-306

Harris GP (1980) Temporal and spatial scales in phytoplankton ecology. Mechanisms, methods, models, and management. Can J Fish Aquat Sci 37:877-900

Heckman CW (1985) The development of vertical migration patterns in the sediments of estuaries as a strategy to resist drift with tidal currents. Int Rev Ges Hydrobiol 70:151-164

Henley WJ (1993) Measurement and interpretation of photosynthetic light-response curves in algae in the context of photoinhibition and diel changes. J Phycol 29:729-739

Hulbert SH (1984) Pseudoreplication and the design of ecological field experiments. Ecol Monogr 54:187-211

Joint IR (1978) Microbial production in an estuarine mudflat. Estuar Coast Mar Sci 7:185-195

Kromkamp J, Barranguet C, Peene J (1998) Determination of microphytobenthos PSII quantum efficiency and photosynthetic activity by means of variable chlorophyll fluorescence. Mar Ecol Prog Ser 162:45-55

Lamontagne I, Cardinal A, Fortier L (1989) Environmental forcing versus endogenous control of photosynthesis in intertidal epilithic microalgae. Mar Ecol Prog Ser 51: $177-1.87$

Laws EA, Archie JW (1981) Appropriate use of regression analysis in marine biology. Mar Biol 65:13-16

Leach JH (1970) Epibenthic algal production in an intertidal mudflat. Limnol Oceanogr 15:514-521

Legendre L, Demers S (1985) Auxiliary energy, ergoclines and aquatic biological production. Nat Can (Rev Écol Syst) $112.5-14$

Leverenz JW (1988) The effects of illumination sequence, $\mathrm{CO}_{2}$ concentration, temperature and acclimation on the convexity of the photosynthetic light response curve. Physiol Plant 74:332-341

Macedo MF, Ferreira JG, Duarte P (1998) Dynamic behaviour of photosynthesis-irradiance curves determined from oxygen production during variable incubation periods. Mar Ecol Prog Ser 165:31-4.3

MacIntyre HL, Geider RJ, Miller DC (1996) Microphytobenthos: the ecological role of the 'secret garden' of unvegetated, shallow-water marine habitats, I. Distribution, abundance and primary production. Estuaries 19 : $186-201$

Margalef R (1992) Population dynamics converges with succesion theory. In: Colombo G, Ferrari I, Ceccherelli VU, Rossi $R$ (eds) Marine eutrophication and population dynamics. Olson \& Olson, Fredensborg, p 135-141

Paterson DM (1986) The migratory behaviour of diatom assemblages in a laboratory tidal micro-ecosystem examined by low temperature scanning electron microscopy. Diatom Res 1:227-239

Pinckney J, Zingmark RG (1991) Effects of tidal stage and sun angles on intertidal benthic microalgal productivity. Mar Ecol Prog Ser 76:81-89

Pinckney JL, Zingmark RG (1993a) Modelling the annual production of intertidal benthic microalgae in estuarine ecosystems. J Phycol 29:396-407

Pinckney JL, Zingmark RG (1993b) Photophysiological responses of intertidal benthic microalgal communities to in situ light environments: methodological considerations Limnol Oceanogr 38:1373-1383 
Platt T, Denman KL (1975) Spectral analysis in ecology. Annu Rev Ecol Syst 6:189-210

Raven JA (1995) Scaling the seas. Plant Cell Environ 18:1090-1100

Revsbech NP, Jørgensen BB (1983) Photosynthesis of benthic microflora measured with high spatial resolution by the oxygen microprofile method: capabilities and limitations of the method. Limnol Oceanogr 28:749-756

Ricker WE (1973) Linear regressions in fishery research J Fish Res Board Can 30:409-434

Round FE, Palmer JD (1966) Persistent, vertical-migration rhythms in benthic microflora. II. Field and laboratory studies on diatoms from the banks of the river Avon. J Mar Biol Assoc UK 46:191-214

Schreiber RA, Pennock JR (1995) The relative contribution of benthic microalgae to total microalgal production in a shallow sub-tidal estuarine environment. Ophelia 42 $335-352$

Serôdio J (1993) Processos de nascimento e morte em ambiente oscilante: modelação estocástica da dinâmica populacional do microfitobentos. MSc thesis, Universidade de Lisboa, Lisbon

Serôdio J, Catarino F (1999) Fortnightly light and temperature variability in estuarine intertidal sediments and implications for microphytobenthos primary productivity. Aquat Ecol 33:235-241

Serôdio J, Marques da Silva J, Catarino F (1997) Nondestruc-

Editorial responsibulity: Otto Kinne (Editor),

Oldendorflluhe, Germany tive tracing of migratory rhythms of intertidal benthic microalgae using in vivo chlorophyll a fluorescence. J Phycol 33:542-553

Shaffer GP, Onuf CP (1985) Reducing the error in estimating annual production of benthic microflora: hourly to monthly rates, patchiness in space and time. Mar Ecol Prog Ser 26:221-231

Sokal RR, Rohlf FJ (1981) Biometry. WH Freeman, New York Sousa WP (1984) The role of disturbance in natural communities. Annu Rev Ecol Syst 15:353-391

Stewart-Oaten A, Murdoch WM, Parker KR (1986) Environmental impact assessment: 'pseudoreplication' in time? Ecology 67:929-940

Sundbäck K (1986) What are the benthic microalgae doing on the bottom of Laholm bay? Ophelia 4:273-286

Terashima I, Saeki T (1985) A new model for leaf photosynthesis incorporating the gradients of light environment and of photosynthetic properties of chloroplasts within a leaf. Ann Bot 56:489-499

Underwood AJ (1994) On beyond BACI: sampling designs that might reliably detect environmental disturbances. Ecol Appl 4:3-15

Vale C. Sundby B (1987) Suspended sediment fluctuations in the Tagus estuary on semi-diurnal and fortnightly time scales. Estuar Coast Shelf Sci 25:495-508

Zedler JB (1980) Algal mat productivity: comparisons in a salt marsh. Estuaries 3:122-131

Submitted: February 15, 1999; Accepted: August 25, 1999 Proofs received from author(s): January 7, 2000 